
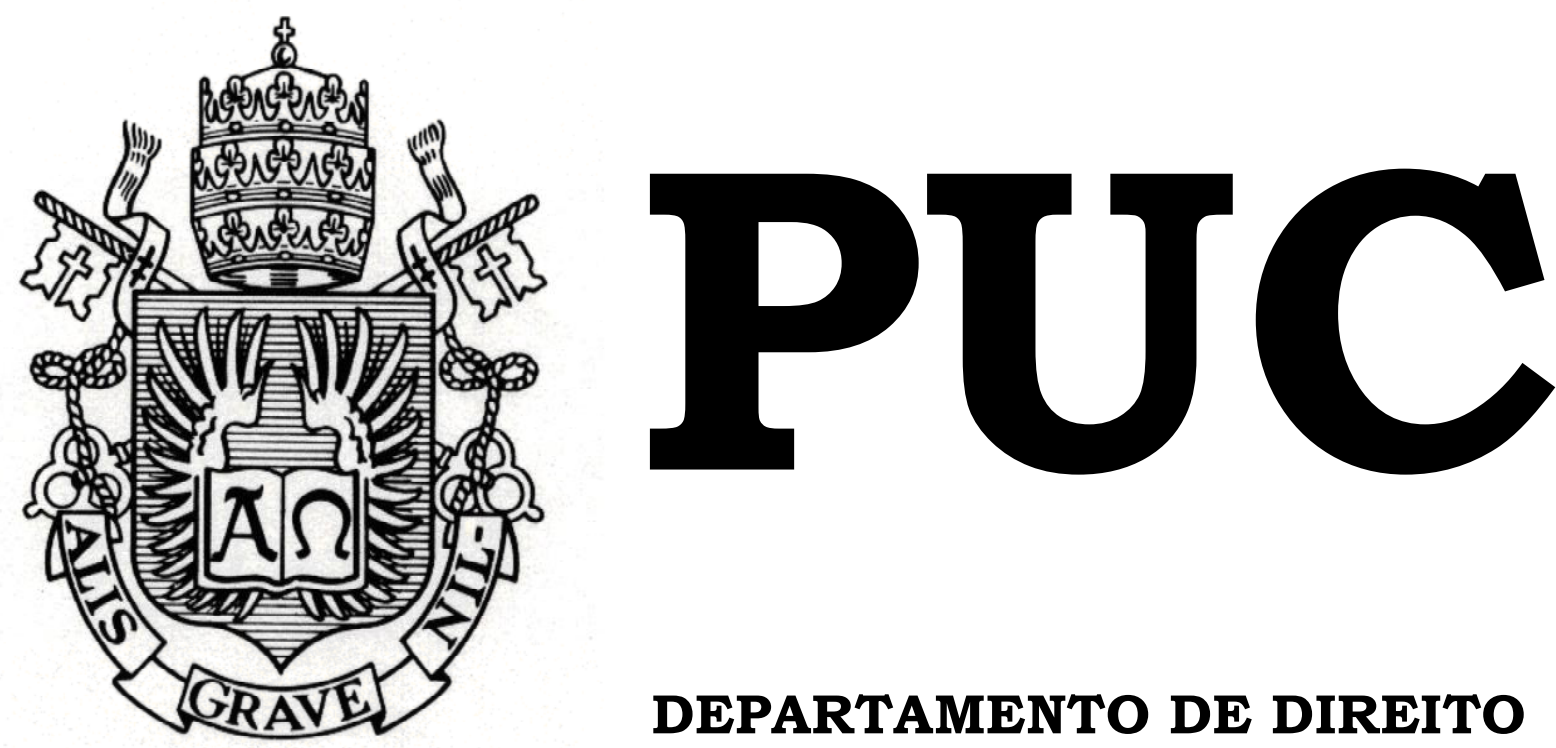

DEPARTAMENTO DE DIREITO

O DIREITO PENAL DO INIMIGO E SUA INCIDÊNCIA NA DECRETAÇÃO DE PRISÕES PREVENTIVAS E NO REGIME DISCIPLINAR DIFERENCIADO

por

Guilherme Alves Cortes da Fonseca

ORIENTADOR: SÉRGIO CHASTINET DUARTE GUIMARÃES

2015.2

PONTIFÍCIA UNIVERSIDADE CATÓLICA DO RIO DE JANEIRO RUA MARQUÊS DE SÃO VICENTE, 225 - CEP 22453-900 RIO DE JANEIRO - BRASIL 


\title{
O DIREITO PENAL DO INIMIGO E SUA INCIDÊNCIA NA DECRETAÇÃO DE PRISÕES PREVENTIVAS E NO REGIME DISCIPLINAR DIFERENCIADO
}

\author{
por \\ Guilherme Alves Cortes da Fonseca \\ Monografia apresentada ao Departamento de \\ Direito da Pontificia Universidade Católica do \\ Rio de Janeiro (PUC-Rio) como requisito parcial \\ para obtenção do título de Bacharel em Direito
}

Orientador: Sérgio Chastinet Duarte Guimarães

2015.2 


\section{Resumo}

No presente trabalho, analisa-se o fenômeno do direito penal do inimigo a partir das formulações teóricas de Günther Jakobs e Eugenio R. Zaffaroni. Parte-se de concepções distintas, que caracterizam o tema a partir de institutos legislativos determinados ou de aspectos históricos, políticos e sociais. Discute-se a penetração do assunto no Brasil por intermédio de ambas as perspectivas. Realiza-se, em um primeiro momento, ampla abordagem histórica, reconhecendo-se a influência no país de um processo de exclusão social iniciado no passado e que tem reflexos no fenômeno da seleção punitiva. Enfatiza-se o papel exercido por atores sociais como os meios de comunicação de massa e os operadores do sistema penal. Passa-se, em seguida, à análise de duas previsões específicas da legislação brasileira, a prisão preventiva e o regime disciplinar diferenciado. Destaca-se a lógica de neutralização de inimigos adjacente aos institutos, diante da singularidade do tratamento conferido pela justiça criminal aos acusados/presos nessas hipóteses. Assinala-se as arbitrariedades cometidas a partir da interpretação de expressões vagas e conceitos indeterminados, em que prevalece uma noção de periculosidade construída a partir de estereótipos criminais socialmente difundidos.

\section{Palavras-chave}

Direito penal do inimigo. Jakobs. Zaffaroni. Poder punitivo. Seletividade. Periculosidade. Estereótipo. Discriminação. Pobreza. Garantias penais e processuais. Prisão cautelar. Presunção de inocência. Ordem pública. Segurança. Regime disciplinar diferenciado. Estabelecimento prisional. Arbitrariedade. Indeterminação linguística. 


\section{SUMÁRIO}

CAPÍTULO I - O FENÔMENO DO DIREITO PENAL DO INIMIGO .................5

1.1 - INTRODUÇÃO .................................................................................. 5

1.2 - A CONSTRUÇÃO DE GUNTHER JAKOBS ............................................. 6

1.2.1 - Características e reflexos na legislação penal.............................................. 7

1.2.2 - Definição do inimigo e legitimação do fenômeno...................................... 10

1.3 - A CONCEPÇÃO DE EUGENIO R. ZAFFARONI ..................................... 12

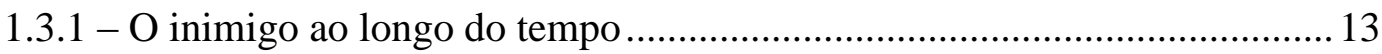

1.3.1.1 - O sistema inquisitorial e o exercício do poder punitivo ........................... 13

1.3.1.2 - O racismo e o inimigo nos séculos XIX e XX ........................................ 15

1.3.1.3 - A guerra fria e as ditaduras militares latino-americanas ......................... 19

1.3.1.4 - Tráfico de drogas, terrorismo e xenofobia no século XXI ..................... 21

1.3.2 - Conclusões: a arbitrariedade na seleção dos inimigos e o poder punitivo .24

1.4 - JAKOBS E ZAFFARONI: ANÁLISE DO FENÔMENO A PARTIR

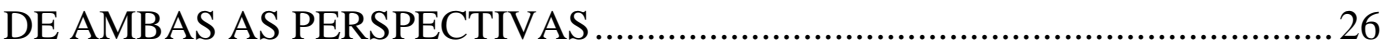

CAPÍTULO 2 - A FORMAÇÃO DO ESTEREÓTIPO DO CRIMINOSO NO

BRASIL E A SELETIVIDADE DA JUSTIÇA CRIMINAL .............................. 28

2.1 - CRIME E EXCLUSÃO SOCIAL: ABORDAGEM HISTÓRICA ................ 29

2.2 - ESTIGMATIZACÃO DO POBRE: PERMANÊNCIAS DO PASSADO ... 34

2.2.1 - Da ditadura militar à redemocratização ...................................................... 36

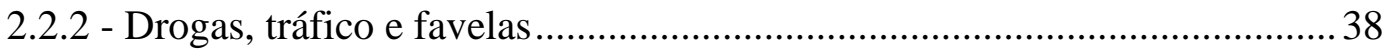

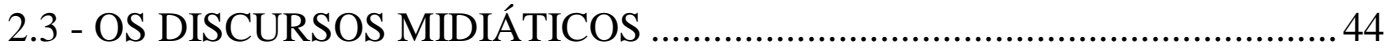

2.4 - A SELETIVIDADE DA JUSTIÇA PENAL ............................................... 47

CAPÍTULO 3 - A DECRETAÇÃO DE PRISÕES PREVENTIVAS PARA A

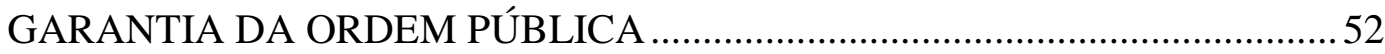

3.1 - A INSTRUMENTALIDADE DA PRISÃO PROVISÓRIA ......................... 52

3.2 - PRESSUPOSTOS E FUNDAMENTOS PARA DECRETAÇÃO DA

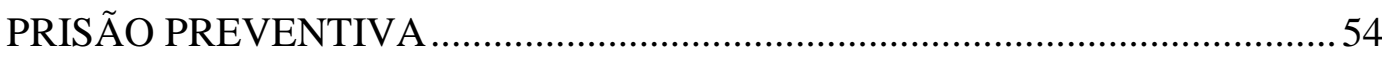




\section{3 - A ORDEM PÚBLICA COMO JUSTIFICATIVA PARA}

DECRETAÇÃO DE PRISÕES PREVENTIVAS ...............................................58

3.4 - ORDEM PÚBLICA E A PERICULOSIDADE DO AGENTE ......................61

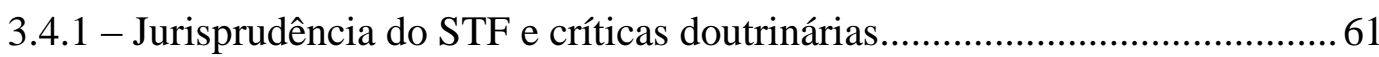

3.4.2 - Prisão preventiva como política de segurança pública: necessidade

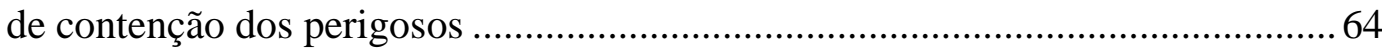

3.4.3 - Direito penal de periculosidade presumida: quando a exceção vira a regra 68

CAPÍTULO 4 - A ALOCAÇÃO DE PRESOS NO REGIME DISCIPLINAR

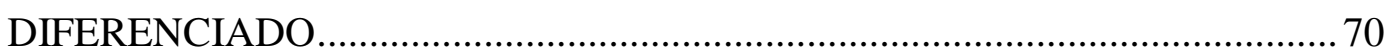

4.1 - A GÊNESE DO RDD: REBELIÕES NOS PRESÍDIOS ............................ 71

4.2 - REGIME DISCIPLINAR DIFERENCIADO: CONCEITUAÇÃO ............. 73

4.3 - CARACTERÍSTICAS DO REGIME DISCIPLINAR DIFERENCIADO ... 74

4.4 - HIPÓTESES QUE AUTORIZAM A APLICAÇÃO DO REGIME

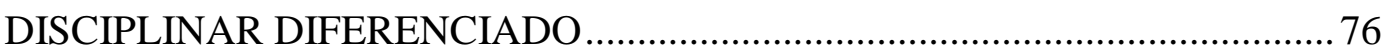

4.4.1 - Regime Disciplinar Diferenciado como punição disciplinar

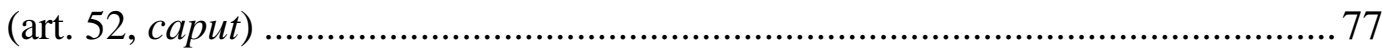

4.4.2 - Regime Disciplinar Diferenciado como medida preventiva/cautelar

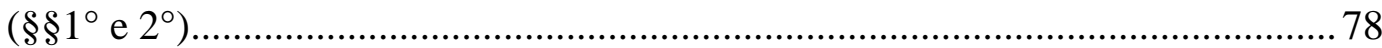

4.5 - O REGIME DISCIPLINAR DIFERENCIADO COMO DIREITO

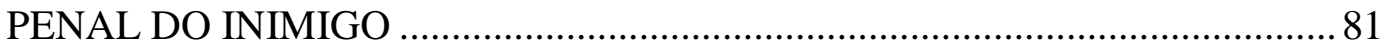

4.6 - PERICULOSIDADE E O ESTEREÓTIPO CRIMINAL …........................... 84

CAPÍTULO 5 - CONSIDERAÇÕES FINAIS …............................................. 86

5.1 - DIREITO PENAL DO INIMIGO: POLÍTICA DE SEGURANÇA

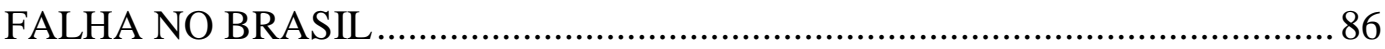

5.2 - PRISÕES PREVENTIVAS E RDD: ASPECTOS JURÍDICOS

COMUNS QUE FAVORECEM A OCORRÊNCIA DO FENÔMENO .............. 89

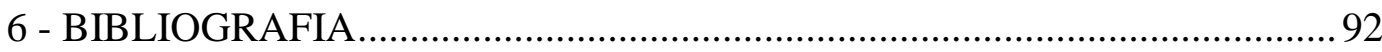




\section{CAPÍTULO I - O FENÔMENO DO DIREITO PENAL DO INIMIGO}

\section{1 - INTRODUÇÃO}

O conceito de inimigo, não obstante tenha surgido para o mundo do direito somente em meados dos anos 80 do século passado, caracteriza uma presença constante na história das sociedades, desde as mais primitivas (pré-modernas) às atuais. Com efeito, ao sistematizar o tema e empregar a terminologia de inimigo, Günther Jakobs teve o mérito de unificar por meio de um nome toda uma gama de indivíduos que, de forma variada e de acordo com o contexto histórico e cultural em que inseridos, foram ou continuam a ser privados da condição de pessoa e, por isso, receberam ou continuam a receber tratamento diferenciado por parte dos demais, das instituições públicas e, no seu bojo, do sistema penal.

A principal característica do inimigo consiste na negação de sua humanidade. Os indivíduos assim considerados representam, aos olhos da coletividade, um risco à ordem social, à manutenção pacífica da vida comum. Assim é que eles somente são analisados sob o aspecto da periculosidade que supostamente apresentam.

Dentro dessa lógica, é justamente o caráter perigoso do inimigo que justifica sua privação de certos direitos individuais garantidos aos demais cidadãos, às "pessoas propriamente consideradas". No mesmo sentido, é também essa suposta ameaça por eles representada que legitima medidas de contenção que são levadas a cabo pelo Estado.

Nas últimas décadas, muito em função da ocorrência de ataques terroristas e da difusão de um discurso de combate ao crime organizado, os países passaram a adotar medidas legislativas extremamente repressivas e restritivas de direitos, promovendo verdadeira interferência na liberdade individual das pessoas. Não há como negar que assistimos a um processo de 
ampliação do poder punitivo, legitimado pela necessidade de enfrentar o perigo representado pela figura do inimigo, seja ele qual for. Trata-se, acima de tudo, de um fenômeno que aparece de forma bastante clara na atualidade.

Dentro desse contexto e buscando identificar o fenômeno, desenvolveram-se formulações doutrinárias sobre o tema, associando-o a aspectos jurídicos, históricos, políticos e econômicos. Vejamos, pois, as concepções atribuídas pela doutrina penal ao fenômeno desde as suas origens, destacando-se a obra de Günther Jakobs e as considerações feitas por Eugenio R. Zaffaroni.

\section{2 - A CONSTRUÇÃO DE GUNTHER JAKOBS}

A terminologia direito penal do inimigo remonta ao ano de 1985, no qual, durante um seminário realizado na cidade de Frankfurt, o professor alemão Günther Jakobs utilizou a expressão pela primeira vez. Nesta ocasião, o jurista preocupou-se em demonstrar como havia uma tendência à punição por antecipação, em se tratando o agente de um inimigo. ${ }^{1}$

A partir daí, foram desenvolvidas distintas construções teóricas, por parte do próprio Jakobs e também de outros penalistas. Neste momento, cabe apresentar a teoria do professor alemão, esmiuçando as características do fenômeno, a identificação do inimigo, bem como a mudança de perspectiva do próprio autor quanto à legitimidade deste processo.

1 SILVA, Ivan Carlos da. $O$ direito penal do inimigo. Disponível em: http://unisinos.br/blogs/ndh/2013/07/29/o-direito-penal-do-inimigo/. Acesso em 29 de jul 2013. 


\subsection{1 - Características e reflexos na legislação penal}

Buscando explicar propriamente o tema, em termos jurídicos, o autor preocupou-se em atribuir-lhe características comuns, quais sejam: (i) a configuração de um amplo adiantamento da punibilidade, que passa a ter por fundamento o risco de lesões futuras; (ii) a previsão de penas demasiado altas e extremamente desproporcionais; (iii) a relativização ou supressão de garantias processuais. ${ }^{2}$

Desde o princípio, Jakobs identifica como uma manifestação de direito penal do inimigo a instituição de uma série de normas que caracterizam verdadeiro avanço na punibilidade, criminalizando estágios prévios à lesão ao bem jurídico, anteriores à prática de um fato. Em suas palavras, "não se trata, em primeira linha, da compensação de um dano à vigência da norma, mas da eliminação de um perigo: a punibilidade avança um grande trecho para o âmbito da preparação, e a pena se dirige à segurança frente a fatos futuros, não à sanção de fatos cometidos.".

Trata-se, com efeito, de normas incriminadoras que prescindem da prática de um fato e/ou da ocorrência de um dano à vítima. Imputa-se ao sujeito uma pena sem que ele tenha agido, ou, ainda que tenha agido, não tenha advindo nenhum resultado danoso de sua conduta.

Nas legislações penais da atualidade, não raro nos deparamos com tipos penais que se encaixam nesta definição, como os de mera conduta, bem como os crimes de perigo abstrato, os delitos de associação ou organização criminosa, dentre outros. Avança-se até o estágio de preparação.

Na interpretação de Cancio Meliá, "mediante sucessivas ampliações, se tem alcançado um ponto no qual 'estar ai' de algum modo, 'fazer parte'

\footnotetext{
${ }^{2}$ JAKOBS, Günther. MELIÁ, Manuel Cancio. Direito Penal do Inimigo: Noções e Críticas, $6^{\mathrm{a}}$ ed. Porto Alegre: Livraria do Advogado, 2012., p. 90.

${ }^{3}$ Idem., p. 34.
} 
de alguma maneira, 'ser um deles', ainda que somente em espirito”, é suficiente para ensejar a criminalização. ${ }^{4}$

Neste sentido, rompe-se, evidentemente, com o postulado liberal tradicional de um direito penal fundado na culpabilidade do agente, que pressupõe a realização de uma conduta no mundo real. Pune-se o agente, portanto, pelo que ele representa, por sua periculosidade em potencial.

Interpretando-se a teoria do penalista alemão, percebe-se que este avanço na punibilidade constitui a peculiaridade principal do fenômeno do direito penal do inimigo, hábil a distingui-lo do que Jakobs concebe como um direito penal do cidadão.

Visualizando o agente como cidadão, o Estado somente está autorizado a agir e interferir em sua liberdade quando o comportamento do sujeito gerar determinado resultado danoso a um bem jurídico protegido pela lei. A pessoa, apesar de transgredir, ainda preserva o seu caráter de cidadão. No caso do inimigo, por sua vez, este não goza de proteção em sua esfera privada, podendo ser penalizado por meras suposições, tendo em vista o caráter de ameaça constante que representa. Assim, conclui-se que a um se aplica um direito penal do fato (cidadão), ao outro um direito penal do autor (inimigo):

\begin{abstract}
"O direito penal conhece dois polos ou tendências em suas regulações. Por um lado, o tratamento com o cidadão, esperando-se até que se exteriorize sua conduta para reagir, com o fim de confirmar a estrutura normativa da sociedade, e por outro, o tratamento com o inimigo, que é interceptado já no estado prévio, a quem se combate por sua periculosidade" .
\end{abstract}

A segunda característica marcante deste processo é a supressão ou restrição de garantias processuais aos inimigos, ampliando-se o grau de interferência do Estado sobre a sua liberdade. Assim, sob pretextos

\footnotetext{
${ }^{4}$ JAKOBS, Günther. MELIÁ, Manuel Cancio. Derecho Penal Del enemigo, $1^{\mathrm{a}}$ ed. Madrid: Civitas, 2003. pp. 101-102

${ }_{5}^{5}$ JAKOBS, Günther. MELIÁ, Manuel Cancio. Direito Penal do Inimigo: Noções e Críticas, $6^{\mathrm{a}}$ ed. Porto Alegre: Livraria do Advogado, 2012. p. 36
} 
investigativos, são criados mecanismos de invasão da esfera privada do sujeito perigoso, a permitir que estes estejam em absoluto controle por parte das autoridades públicas.

Como exemplos dessa tendência, a introdução de medidas de ampla intervenção nas comunicações para fins de investigação, a relativização ao princípio da presunção da inocência através de prisões provisórias e arbitrárias, o desenvolvimento de investigações secretas, a infiltração de agentes policiais em supostos grupos criminosos, a colheita do material biológico do réu para fins de prova, dentre outras.

Ao tratar do tema, Jakobs faz referência a determinados institutos do Código de Processo Penal Alemão, para afirmar que se tratam de "medidas de supervisão das quais o imputado nada sabe no momento de sua execução porque as medidas só funcionam enquanto o imputado não as conheça. Neste sentido, há que mencionar a intervenção nas telecomunicações (\$100 a StPO), outras investigações secretas (\$100 c StPO), e a intervenção de agentes infiltrados (\$ 110 a StPO) ". ${ }^{6}$

Indo mais além, refere-se ainda à possibilidade de coação do agente para uma retirada de sangue, bem como à exigência de incomunicabilidade, ou seja, "à eliminação da possibilidade de um preso entrar em contato com o seu defensor, evitando-se riscos para a vida, a integridade física ou a liberdade de uma pessoa".

Como se vê, tais medidas acarretam restrições não apenas à liberdade, como também ao direito à privacidade do indivíduo, chegandose, em casos extremos, a restringir o próprio exercício do seu direito de defesa, impossibilitando-o de se comunicar com o seu advogado.

Por fim, a terceira característica que permite identificar o fenômeno no âmbito da legislação é a cominação de penas elevadas e desarrazoadas,

\footnotetext{
${ }^{6}$ JAKOBS, Günther. MELIÁ, Manuel Cancio. Idem, p. 38.

${ }^{7}$ Idem, Ibidem.
} 
totalmente desproporcionais à conduta do agente (se é que fora exteriorizada uma conduta). Trata-se de um claro esforço de contenção de potenciais inimigos. Aparece aqui de forma evidente a perspectiva do Estado de retirar sujeitos ditos perigosos do convívio com os denominados cidadãos. Portanto, vê-se a pena tão somente sob o aspecto da neutralização.

\subsection{2 - Definição do inimigo e legitimação do fenômeno}

Diante de todo esse aparato repressivo previsto na legislação e que autoriza as autoridades públicas a invadirem a esfera individual destes inimigos sobremaneira, convém então indagar quem eles seriam e por que estaria legitimado esse controle e vigilância ostensivos por parte do Estado.

A definição de inimigo sugerida por Jakobs surge em sua segunda formulação teórica sobre o fenômeno, momento em que passa a contemplar meios para afirmá-lo, julgando-o inevitável na atualidade.

Na primeira aproximação do autor com o tema, é perceptível a concepção crítica por ele adotada. No início, Jakobs entendia que a adoção de um direito penal do inimigo representava verdadeira contradição para com regimes democráticos, impassível de conciliação com as garantias e liberdades individuais consagradas nessas democracias. Assim, somente seria justificável restringir a liberdade, conferir tratamento diferenciado e adotar tais medidas repressivas em situações de emergência. ${ }^{8}$

No entanto, tempos depois, com a obra "Derecho Penal Del Enemigo", de 2003, o autor consolida posição favorável ao fenômeno, passando a afirmá-lo e defendendo uma sistematização clara no âmbito da legislação penal. Ao que parece, analisando-se o seu trabalho, é possível

8 SILVA, Ivan Carlos da. $O$ direito penal do inimigo. Disponível em: http://unisinos.br/blogs/ndh/2013/07/29/o-direito-penal-do-inimigo/. Acesso em 29 de jul 2013. 
dizer que o penalista fora em muito influenciado pelo desenvolvimento de grupos terroristas e pelos trágicos incidentes ocorridos no início deste século nos EUA e, após, na Europa.

Nesta sua segunda construção teórica, marcada por uma mudança de perspectiva sobre o assunto, o autor buscou identificar o inimigo recorrendo às formulações da filosofia, sobretudo à obra de Thomas Hobbes e Immanuel Kant. Na interpretação do alemão, o indivíduo perigoso é aquele que, pretendendo regressar ao estado de natureza, entendido como o ambiente no qual não há qualquer tipo de comando que estabeleça a ordem, se comporta como uma ameaça constante ao sistema estabelecido, gerando instabilidade e insegurança aos cidadãos. ${ }^{9}$

Deste conceito, depreende-se que a figura do inimigo reside sobre aquele que não se comporta como ser social, que não demonstra qualquer expectativa de respeito em relação à sociedade. Nas suas palavras, "um indivíduo que não admite ser obrigado a entrar em um estado de cidadania não pode participar dos benefícios do conceito de pessoa". 10

Com efeito, trata-se de alguém que desafia a própria existência do Estado, através de uma conduta reiterada em desconformidade com o ordenamento jurídico, devendo ser combatido em razão da sua periculosidade.

Note-se que a adequação dessa noção de inimigo ao conceito que se tem de um terrorista é evidente. O próprio autor define um terrorista como alguém que rejeita deliberadamente a legitimidade do ordenamento jurídico, buscando o seu aniquilamento. ${ }^{11}$

\footnotetext{
9 GARCIA, Manuel Salvador Grosso. "Qué es y qué puede ser el Derecho penal del enemigo?" Una aproximación crítica al concepto. In: MELIÁ, Manuel Cancio e DIEZ, Gomés-Jara (coord.). Derecho Penal del Enemigo: el Discurso de la Exclusion, vol. 2. Madrid: Edisofer, 2006, p. 10.

${ }^{10}$ JAKOBS, Günther. MELIÁ, Manuel Cancio. Op. Cit, p.35.

${ }^{11}$ Idem, ibidem.
} 
Assim, para legitimar a diferenciação de tratamento conferida a essa classe de indivíduos e a instituição de medidas de controle demasiado invasivas, Jakobs ressalta que se trata de um imperativo de segurança, da obrigação de garantir à coletividade um direito que lhes é inerente:

Quem por princípio se conduz de modo desviado não oferece garantia de um comportamento pessoal. Por isso, não pode ser tratado como cidadão, mas deve ser combatido como inimigo. Esta guerra tem lugar com um legítimo direito dos cidadãos, em seu direito à segurança. ${ }^{12}$

Por essa razão, o autor defende uma sistematização precisa desse processo no âmbito da legislação, para garantir o direito à segurança das pessoas e, sobretudo, para evitar que determinadas regulações restritivas típicas desse fenômeno sejam aplicadas aos cidadãos (não inimigos). ${ }^{13}$

De fato, na atualidade, as legislações características de um direito penal do inimigo são normalmente veiculadas como questões de segurança nacional. Tais normas demasiado restritivas de direitos sempre vem acompanhadas de um discurso de que se faz necessário conter determinadas ameaças à população. Na concepção de Jakobs, portanto, tais medidas seriam legítimas justamente por prevenir violações aos direitos dos cidadãos, garantindo-lhes segurança.

\section{3 - A CONCEPÇÃO DE EUGENIO R. ZAFFARONI}

Contrariamente ao que propõe Günther Jakobs, o criminólogo e ministro da Suprema Corte Argentina Eugênio R. Zaffaroni adota postura crítica em relação ao fenômeno do direito penal do inimigo, sustentando a tese de que este processo seria totalmente incompatível com os princípios consagrados nos regimes democráticos de direito.

\footnotetext{
12 Idem. p. 47.

${ }^{13}$ Idem, ibidem.
} 
Em sua opinião, a admissão da figura do inimigo é traço característico do Estado absoluto, violador de direitos e garantias individuais, nos quais não há limites à atuação repressiva desempenhada pelas agências que compõem o denominado poder punitivo. ${ }^{14}$

Assim, para demonstrar o seu ponto de vista, o penalista argentino recorre à história, para evidenciar como o rótulo do inimigo sempre existiu e recaiu sobre as figuras mais diversas ao longo do tempo, selecionadas de modo arbitrário pelos núcleos de poder dentro da sociedade.

Com efeito, em sentido oposto à ideia de Jakobs de que este tratamento diferenciado conferido ao inimigo se justificaria por um imperativo de segurança, Zaffaroni intenta demonstrar como, na verdade, esse discurso de instabilidade e insegurança sempre fora justamente a base utilizada para legitimar as mais diversas atrocidades, tratando-se, na prática, de mera retórica hábil a garantir ao Estado os meios necessários para estreitar os mecanismos de controle sobre a população, mantendo-se o status quo ante.

Para demonstrar a sua tese, imprescindível a realização de uma abordagem histórica sobre o tema, capaz de evidenciar através de fatos essa atuação arbitrária por parte das instâncias de poder, extraindo-se características comuns entre os distintos processos de seleção e segregação dos inimigos ao longo dos anos.

\subsection{1 - O inimigo ao longo do tempo}

\subsubsection{1 - O sistema inquisitorial e o exercício do poder punitivo}

Ainda que a provável origem do fenômeno remonte à antiguidade, ao processo de segregação entre os cidadãos romanos e os inimigos da época,

${ }^{14}$ ZAFFARONI, E. Raul. O inimigo no Direito Penal, $3^{\text {a }}$ ed. Rio de Janeiro: Revan, 2011, p. 12. 
denominados hostis, fato é que a sua primeira manifestação clara ocorreu nos séculos XII e XIII, momento em que o Estado tomou para si o monopólio da decisão de conflitos, estruturando-se o poder punitivo.

Contrariamente ao regime feudal predominante durante quase todo o período de Idade Média, em que os conflitos eram decididos de forma privada, eis que não havia centralização do poder político, nesse momento a solução privada de conflitos é abandonada e estes passam a ser resolvidos pela figura do agente inquisidor.

A inquisição é o primeiro sistema penal a trazer um discurso estruturado, instâncias judiciais burocratizadas, regras processuais próprias, marcadas por um forte conteúdo de caráter religioso. Nesse sistema, releva notar como a identificação do inimigo variava conforme a necessidade, sempre individualizando-se aqueles que representavam ameaças ao poder do Papado. Revela-se desde cedo, portanto, um oportunismo muito grande na seleção dos perigosos:

\footnotetext{
"o inimigo desta empresa, depois da extinção dos infelizes albigenses e cátaros, era Satã, o que deu lugar à primeira de uma longa lista de emergências, que seguiriam pelos séculos afora até a atualidade, ou seja, ameaças mais ou menos cósmicas ou apocalípticas que justificam uma guerra e, por conseguinte, demandam a individualização de um inimigo" 15
}

Com efeito, em um primeiro momento, discriminavam-se os dissidentes, aqueles que não estavam alinhados à cultura da igreja católica e, em seguida, as bruxas, fortemente associadas à ideia de inferioridade da mulher e consideradas representantes de Satã na Terra. À época da Contrarreforma, a Inquisição se reorganizou e passou a combater os hereges luteranos, potenciais ameaças à hegemonia católica. Em comum, sempre a necessidade de reprimir possíveis entraves à manutenção de seus interesses. $^{16}$

\footnotetext{
${ }^{15}$ ZAFFARONI, E. Raul. Idem, p. 33.

${ }^{16}$ Idem, p. 88
} 
Nesse contexto, criavam-se ameaças apocalípticas que disseminavam o medo na população, instabilidade que justificava o exercício diferenciado do poder punitivo sobre essas figuras. ${ }^{17}$

Para legitimar as atrocidades cometidas durante o processo penal inquisitorial, como torturas e degolas, identificava-se no inquisidor a figura divina, a representação de Deus. Tratava-se, por excelência, daquele que conhece o bem e o que representa o mal. Desse modo, sabendo-se que o inquisidor era a personificação do bem, todo e qualquer esforço poderia ser empreendido para desmascarar o mal. ${ }^{18}$

A partir de justificativas sobrenaturais, com o apelo à religião, era possível à Igreja Católica legitimar a barbárie e manter o controle sobre os indivíduos através desse aparato repressivo, mediante coação.

\subsubsection{2 - O racismo e o inimigo nos séculos $X I X$ e XX}

Tempos depois, com o triunfo da revolução francesa, que representou o colapso do antigo regime e da sociedade estamental, inaugurou-se uma nova era, marcada pela laicização do Estado, o surgimento do capitalismo, a ascensão da burguesia, a revolução industrial e a expansão urbana. Durante o século XIX, as sociedades europeias vivenciaram uma série de transformações no campo político, econômico e social, e essas inovações também se refletiram na forma com que o Estado passou a tratar os perigosos e buscou justificar a repressão a estes indivíduos.

Muito embora tenham os liberais burgueses lutado contra o excessivo domínio que era exercido pela nobreza e pelo clero, com um discurso, inclusive, de redução da arbitrariedade penal, a partir do momento

\footnotetext{
${ }^{17}$ Idem, p. 86

${ }^{18}$, Idem, p. 40-41.
} 
em que a burguesia se afirmou como classe hegemônica, foi preciso manter a seletividade do poder punitivo, para garantir a ordem recém-construída e possibilitar o desenvolvimento harmônico dessa nova classe social. ${ }^{19}$

Isso porque, com a expansão do sistema capitalista, diversas contradições passaram a ser identificadas: o processo de acumulação de riquezas nas mãos dos proprietários intensificou as desigualdades sociais; a introdução de máquinas nas indústrias contribuiu para a ampliação do quadro de desemprego; o crescimento demográfico acelerado levou ao inchaço das populações urbanas e ao aumento da população sem-teto. Todos esses fatores tiveram como consequência a intensificação da pobreza, a insatisfação com a vida nas cidades e, por fim, o aumento da delinquência. ${ }^{20}$

Frente a esse contexto de instabilidade, fez-se necessário criar um discurso apto a centralizar nos descontentes a figura do inimigo, a associar ao fenômeno da delinquência aqueles que representavam uma ameaça ao funcionamento normal do sistema vigente.

Diante da influência exercida pela filosofia positivista e da crença no progresso das ciências naturais, buscou-se justificar o fenômeno da delinquência e estereotipar o criminoso com base em aspectos de caráter biológico, a partir de características naturais desses indivíduos. A ideia, difundida pela criminologia positivista da época e desenvolvida por Cesare Lombroso, era a de que o indivíduo nasce em condição de inferioridade, sua estrutura física e psíquica é inferior por razões alheias à sua vontade.

Desse modo, com base em argumentos racistas em muito influenciados pela teoria do darwinismo social, na crença de que haveria estágios de evolução das espécies, impôs-se a neutralização dos seres

\footnotetext{
${ }^{19}$ ZAFFARONI, E. Raul. Idem, p. 43.

${ }^{20}$ DEL OLMO, Rosa. A América Latina e sua criminologia, $1^{\mathrm{a}}$ ed. Rio de Janeiro: Revan, 2004. pp. 43-44.
} 
degenerados, que representavam uma ameaça à prosperidade do povo europeu:

\begin{abstract}
"A superioridade - tal como formulava o evolucionismo - era o resultado da seleção natural transmitida geneticamente. Os seres "inferiores" (leia-se: não proprietários) estavam obrigados à obediência e submissão por sua inferioridade (...) $\mathrm{O}$ criminoso, o anti-social e o socialmente necessitado pertenciam a uma raça inferior em relação à raça 'respeitável' e podiam ser reconhecidos por sinais tais como a medida do crânio e outras formas igualmente simples"21
\end{abstract}

Dentro desse espectro de ameaça compreendiam-se os criminosos graves, os pequenos ladrões, as prostitutas, os homossexuais, os bêbados, os vagabundos e qualquer dissidente que, com o seu comportamento, buscasse subverter a ordem social. ${ }^{22}$

Note-se como, por meio de um discurso que se pretendeu científico, buscou-se garantir uma justificação mais forte, porque originária da ordem natural das coisas e, desse modo, inquestionável. O discurso que legitima o poder punitivo, outrora aceito de maneira inconteste pela suposta representação de Deus por parte do inquisidor, agora era acolhido por retratar fenômenos naturalísticos e, como tais, reais, objetivos, apriorísticos:

\footnotetext{
“o importante era o método cientifico que apregoava a ciência 'positiva' e esta, "ao operar sobre fatos objetivos e determinados, conectados por rígidas relações de causa e efeito, e ao produzir 'leis' gerais, uniformes e invariáveis, acima de toda dúvida ou modificação voluntária, era a chave-mestra do universo e o século XIX seu senhor. O estudo da delinquência seguiria o mesmo caminho. ${ }^{23}$
}

Esse discurso racista pautado na inferioridade biológica persistiu durante a expansão imperialista do final do século XIX e início do século XX, justificando a dominação sobre os povos locais. Os nativos eram considerados inimputáveis, os mestiços eram tidos como loucos morais em potencial e os mais rebeldes eram vistos como selvagens, inimigos da

\footnotetext{
${ }^{21}$ DEL OLMO, Rosa. Idem, p. 44-45.

22 ZAFFARONI, E. Raul. Op. cit, p. 93-94.

${ }^{23}$ DEL OLMO, Rosa. Op. Cit, p.39.
} 
civilização. Contra eles, o exercício do poder repressivo era implacável, sobretudo quando resistiam e se negavam a fornecer sua força de trabalho. ${ }^{24}$

Na primeira metade do século XX, a ascensão de regimes totalitários assistiu ao mesmo processo de estigmatização de indivíduos potencialmente perigosos com base em justificativas de caráter biológico. $\mathrm{O}$ racismo fora a base para tratamentos repressivos nos regimes fascista italiano e, sobretudo, nazista da Alemanha de Hitler. Não há como negar que cada uma dessas experiências totalitárias, à sua medida, se orientou por uma ideia de periculosidade racista e legitimou a utilização desmedida do aparato policial com base na ilusão de uma situação de emergência, em um mito.

No caso da Alemanha, para além dos já conhecidos argumentos de caráter antissemita, criou-se o mito de que os judeus e os comunistas teriam traído a pátria e levado o país para a derrota na Primeira Guerra Mundial:

\footnotetext{
“(...) por detrás de toda individualização de um inimigo há um mito que lhe pretende conferir um caráter ôntico. Em relação a esse complemento nazista aos mitos tradicionais, agregava-se o fato de os judeus e os comunistas - categorias que, em parte, se superpunham - terem traído a Alemanha e terem levado o país à derrota na Primeira Guerra Mundial" 25
}

Tratava-se, no imaginário popular, de duas características que representavam verdadeiro atraso à sociedade alemã e, por isso, aqueles que as apresentassem deveriam ser neutralizados urgentemente.

No caso da URSS, sobretudo durante o período stalinista, para além daqueles que sofriam preconceito natural, a imagem do perigoso residia nos denominados "inimigos da revolução", compreendidos neste grupo todos aqueles que, com o seu comportamento, representavam entraves ao triunfo do socialismo no país.

$\mathrm{Na}$ prática, como se sabe, esse discurso emergencial apenas fora invocado para legitimar todo tipo de arbitrariedade policial contra os que se

\footnotetext{
${ }^{24}$ ZAFFARONI, E. Raul. Op. Cit. p.47.

${ }^{25}$ ZAFFARONI, E. Raul. Idem. p.105.
} 
colocavam no caminho do ditador, seja por discordarem da forma com que conduzia a política, seja por resistirem à repressão dos grandes expurgos, ou até mesmo por representarem uma ameaça à manutenção da barbárie. Como resultado desse processo, inúmeras perseguições políticas e um número absurdo de assassinatos públicos.

Note-se ainda que, nesses regimes, a desigualdade de tratamento penal entre os "cidadãos" e os "inimigos" era nítida: os inimigos do Estado eram submetidos a um sistema penal paralelo, composto por tribunais especiais inquisitoriais. $\mathrm{O}$ sistema penal formal desses regimes, previsto em lei, era tímido e não dava a dimensão exata das atrocidades que eram cometidas. Na prática, operava um sistema penal subterrâneo, sem lei e, portanto, sem qualquer tipo de limite. ${ }^{26}$

\subsubsection{3 - A guerra fria e as ditaduras militares latino-americanas}

Durante o período da Guerra Fria, o principal inimigo norteamericano e o principal inimigo da URSS eram, obviamente, uns aos outros, e ambas as nações trataram de instrumentalizar o seu poder punitivo em função dessa polarização, participando ativamente de conflitos que ameaçavam a perda de determinados territórios estratégicos, intervindo militarmente em regiões aliadas ao adversário e intensificando sua produção de armas de destruição em massa.

Nesse contexto de conflito, legitimava-se a militarização dos Estados por meio de um discurso ideológico de progresso da sociedade com base no regime político vigente e a ameaça representada pelo regime que com ele rivalizava. Em um esforço de afirmação desta retórica, os governos desses dois países promoveram intensas campanhas publicitárias, buscando

${ }^{26}$ Idem, p. 54-55. 
expandir os seus domínios sobre outros locais, o estabelecimento de novas áreas de influência.

Como exemplo claro dessa pretensão universalizante, é de se destacar a influência exercida pelos Estados Unidos no estabelecimento de regimes militares na América Latina, a partir dos anos 60. Sob o pretexto de evitar a ameaça que um governo comunista poderia representar, setores conservadores dos países da América Latina se organizaram e, a partir do suporte recebido pelos Estados Unidos, provocaram golpes de estado, instituindo ditaduras militares.

Durante esses regimes ditatoriais, o terrorismo de estado fora praticado com intensa crueldade e as garantias penais totalmente abolidas. A definição do inimigo nesses regimes, como era de se esperar, se centrou na figura do comunista e do subversivo, considerados obstáculos ao progresso. A repressão autoritária nesse período não se deteve aos grupos radicais armados, como também a todo e qualquer indivíduo que, de alguma forma, apresentasse qualquer manifestação ideológica e comportamental diversa da que lhe impunha o poder central.

Sob a justificativa de que a ameaça comunista era constante e que as atividades subversivas eram extremamente prejudiciais ao desenvolvimento desses países, incrementou-se o aparato policial do Estado, por meio da elaboração de doutrinas de segurança nacional, estigmatizando-se, expressamente, aqueles que eram considerados inimigos do poder público.

A característica marcante dessas ditaduras fora a criação de um sistema penal clandestino, que conferia tratamento diferenciado aos perseguidos pelas autoridades estatais, mediante torturas físicas e psicológicas, homicídios, desaparecimentos forçados, violações sexuais, dentre outras práticas. 
O poder punitivo, mais uma vez, mostrava sua feição seletiva, em função dos discursos de emergência propagados e da necessidade de neutralizar os resistentes.

\subsubsection{4 - Tráfico de drogas, terrorismo e xenofobia no século XXI}

Após o fim da Guerra Fria e a restauração da democracia nos países latino-americanos, difundiu-se no continente americano um discurso de combate direto ao tráfico de drogas, a partir do endurecimento da legislação penal e da mobilização do aparato policial para este fim.

Dentro dessa lógica, o traficante de drogas é visto como alguém extremamente perigoso, que pretende enfraquecer a sociedade e denegrir a integridade moral das pessoas. Cria-se, por conseguinte, o cenário adequado para a edição de leis aptas a legitimar um tratamento penal diferenciado a estes indivíduos, mediante violação de garantias constitucionais penais fundamentais. $^{27}$

Tais legislações autoritárias optaram por adotar uma série de medidas classificadas por Jakobs como características do fenômeno do direito penal do inimigo: a quebra do sigilo das comunicações, a valorização da infiltração de agentes, a banalização do instituto da prisão preventiva, dentre outras. Ressalte-se, inclusive, que muitas dessas leis continuam vigentes em muitos países da América.

Além disso, no início do século XXI, o mundo dera um passo ainda maior neste processo de ampliação do poder punitivo: com a ocorrência do atentado de 11 de setembro de 2001, os Estados Unidos desenvolveram seu mais novo inimigo, o terrorismo.

${ }^{27}$ ZAFFARONI, E. Raul. Idem, p. 51-52. 
A partir de um fato concreto e extremamente traumático, justificouse o endurecimento da lei penal, o controle rigoroso sobre os estrangeiros e o fortalecimento do aparato repressivo do Estado. Nesse contexto, com a extensão do fenômeno da globalização, a ameaça terrorista acabou ganhando dimensões planetárias.

No caso do terrorismo, o problema reside justamente nos excessos que são legitimados a partir da ocorrência de um crime: sob a justificativa de combater o terrorismo, conceito extremamente aberto e indeterminado, legitimaram-se grandes arbitrariedades por parte do aparato policial norteamericano. A maior delas talvez tenha sido a invasão extremamente controversa do Iraque em 2003, pautada em um discurso de que estariam sendo produzidas armas de destruição em massa. Até hoje essas evidências não foram encontradas e milhares de vidas foram sacrificadas por conta dessa ânsia punitiva desmedida.

Trata-se justamente da necessidade de instituir um mito, de criar uma situação de emergência que justifique a utilização de um poder repressivo sui generis. Conquanto não se possa desprezar toda a dor causada pelo fatídico episódio do 11/09, não há dúvidas de que ele forneceu as bases para a criação de um novo inimigo, para a idealização de um estereótipo de criminoso pautado na figura do árabe muçulmano, alimentando preconceitos da sociedade ocidental para com eles, limitando suas oportunidades nos países europeus e intensificando uma relação de ódio.

Dentro dessa tendência ao fortalecimento de preconceitos, é de se destacar também a discriminação aos imigrantes em solo europeu. Com o fim da Guerra Fria e o elevado padrão de vida alcançado pelos países da Europa Ocidental, intensificou-se um movimento migratório em direção a essas nações. Devido à facilidade de acesso, diversas pessoas saem da África em busca de melhores condições no velho continente. Para além da África, também passam a concorrer com os europeus por emprego, 
moradia, serviços e assistência social os asiáticos, árabes e outros povos estrangeiros. $^{28}$

Face a essa concorrência gerada pela chegada de imigrantes, fortalece-se a xenofobia e o preconceito por parte das populações europeias. Cria-se, com isso, o estereótipo do inimigo, que se distingue pela cor da pele, pelo idioma, vestimentas, costumes, etc. Ademais, muitas vezes esses imigrantes são muçulmanos e, com isso, se encaixam ao perfil do terrorista. $^{29}$

Tal discurso que discrimina os imigrantes e lhes retira a humanidade, em muito difundido por partidos de extrema direita dos países centrais europeus, acaba ganhando força em momentos de instabilidade, a partir de episódios isolados de terrorismo, como no caso do atentado ao metrô de Londres em 2005 ou à sede do periódico Charlie Hebdo em Paris, no início deste ano de 2015.

De fato, a discriminação aos "potenciais inimigos" ainda permanece atual, identificando-se o perigo a partir da nacionalidade, caracteres físicos, local de habitação, religião, dentre outros aspectos comuns, intimamente associados a um processo histórico de construção de estereótipos criminais.

A partir de episódios traumáticos, legitima-se um controle exacerbado por parte das autoridades estatais, as quais produzem muitas vezes excessos reprováveis. Com o tempo, esses preconceitos são difundidos e assimilados pelas pessoas, dificultando a convivência entre povos e culturas distintas.

\footnotetext{
${ }^{28}$ ZAFFARONI, E. Raul. Idem. p.67.

${ }^{29}$ ZAFFARONI, E. Raul. Idem, ibidem.
} 


\subsection{2 - Conclusões: a arbitrariedade na seleção dos inimigos e o poder punitivo}

Analisadas todas essas manifestações do denominado direito penal do inimigo, pode-se concluir que a escolha do perigoso recaiu sob figuras extremamente distintas uma das outras, algumas delas impensáveis na atualidade, conforme o discurso de emergência suscitado, os preconceitos difundidos dentro da sociedade e as lideranças de poder nesses momentos determinados.

Com efeito, segundo Zaffaroni, ainda que se possa atribuir características comuns aos inimigos, é evidente que eles se modificam, se extinguem ou se renovam no tempo e nos grupos sociais em que inseridos. Desde sempre, a identificação do "estranho" pressupôs a individualização de um ser humano como tal. O grau de periculosidade do inimigo e, portanto, da necessidade de contenção, dependerá sempre do juízo subjetivo daquele que o individualiza.

Essa tarefa de individualização, evidentemente, sempre ficou a cargo das instituições que detém influência, que exercem poder na sociedade: a igreja, o Estado, os meios de comunicação de massa, dentre outros, conforme a época que se pretenda analisar.

Isto porque, para que se possa dominar uma determinada sociedade e manter a hierarquização social nela compreendida, incumbe aos que detém o poder o imperativo de ordená-la, criando mecanismos de controle eficazes sobre a população. É nesse esforço de organização que se desenvolve e se aprimora o poder punitivo.

Por definição, trata-se o poder punitivo do conjunto de agências executivas do Estado encarregadas da coerção ${ }^{30}$. A partir da sua instituição,

\footnotetext{
${ }^{30}$ ZAFFARONI, E. Raul. Idem. p.27.
} 
a decisão acerca dos conflitos (mesmo privados) é transferida ao poder público. É ele que passa a ter a atribuição privativa de dirimir as controvérsias e, se necessário, se utilizar da força para fazer valer sua vontade. ${ }^{31}$

Não há como negar que, nesse processo, adquiriu o Estado enorme capacidade de decisão nos conflitos, tendo em vista se tratar da única instância capaz de deliberar e poder fazer valer sua deliberação por meio da coerção. Desse modo, o exercício do poder punitivo acaba por abrir espaço para atuações arbitrárias, na medida em que o poder público passa a ter a liberdade de escolher as pessoas contra as quais deseja exercer o poder, bem como a medida e a forma de exercê-lo. ${ }^{32}$

Com efeito, mostra-se evidente que a institucionalização das agências do poder punitivo permitiu ao Estado manter os sujeitos considerados perigosos em constante vigilância, além de criar as condições para que a eles fosse atribuído tratamento diferenciado, em razão da sua (suposta) periculosidade.

Complementarmente, para que esse sistema pudesse ser legitimado e operacionalizado de forma eficaz, necessário se fez o desenvolvimento de discursos capazes de justificar de modo autêntico o tratamento discriminatório conferido aos estranhos pelo poder punitivo. Assim é que toda discriminação é precedida de uma justificativa, a qual é amplamente difundida, seja através de propaganda ideológica estatal, campanhas publicitárias ou por meios de comunicação de massa.

Quanto à essas criações discursivas aptas a legitimar tratamentos discriminatórios a inimigos, na grande maioria das vezes elas se baseiam em supostas ameaças à própria sobrevivência da sociedade, se justificam mediante o desenvolvimento de situações de emergência que demandam

\footnotetext{
${ }^{31}$ ZAFFARONI, E. Raul. Idem. p.30.

${ }^{32}$ Idem. p. 31 .
} 
uma atuação repressiva ilimitada. É por isso que a ampla difusão do medo no todo social é fundamental para dar coesão a essa sistemática. ${ }^{33}$

Portanto, é de se concluir que a imensa gama de inimigos produzida ao longo dos séculos somente ratifica a ideia de que a sua qualificação é realizada com extrema arbitrariedade, de acordo com a perspectiva daqueles que de algum modo exercem influência dentro da sociedade. Sem dúvida alguma, assim procederam da forma que melhor lhes conviesse, que fosse mais funcional à estabilização de seus interesses.

\section{4 - JAKOBS E ZAFFARONI: ANÁLISE DO FENÔMENO A PARTIR DE AMBAS AS PERSPECTIVAS}

As concepções de Günther Jakobs e de Zaffaroni, portanto, caracterizam o fenômeno do direito penal do inimigo sob perspectivas distintas: o alemão identifica a sua existência através de institutos específicos da legislação penal, que (i) incriminam sujeitos com base na sua periculosidade em potencial; (ii) restringem garantias processuais; (iii) cominam penas exacerbadas.

$\mathrm{O}$ argentino, por sua vez, associa o fenômeno a processos sociais e históricos de discriminação e segregação que negam a determinados indivíduos a condição de pessoa, rotulando-os tão somente a partir do caráter de ameaça que representam. Dentro desse processo, a elaboração de legislações autoritárias e restritivas de direito seriam reflexo de um contexto social de estigmatização, estando diretamente associadas aos objetivos das instâncias de poder, utilizando-se do poder punitivo para manter a ordem estabelecida.

${ }^{33}$ Idem, p.34. 
Ao analisarmos a incidência do direito penal do inimigo no Brasil, levaremos em consideração não apenas construções legislativas típicas do fenômeno, como também os processos históricos de estigmatização e discriminação sobre determinada classe de indivíduos. Utilizaremos como base, portanto, ambas as concepções apresentadas neste capítulo.

Primeiramente, analisaremos o tema do ponto de vista social e histórico para, em seguida, examinar detidamente duas expressões do fenômeno no âmbito da legislação (prisões preventivas e regime disciplinar diferenciado). 


\section{CAPÍTULO 2 - A FORMAÇÃO DO ESTEREÓTIPO DO CRIMINOSO NO BRASIL E A SELETIVIDADE DA JUSTIÇA CRIMINAL}

No Brasil, o fenômeno do direito penal do inimigo incide de maneira extremamente natural, uma vez que a hierarquização da sociedade e as desigualdades nela observadas foram há tempos assimiladas, podendo ser facilmente identificados os mecanismos de controle exercidos sobre a população diariamente. Conforme enuncia a socióloga Vera Malaguti Batista, é justamente na "assimilação da manipulação das coisas que se assimilam as relações sociais, ou seja, o homem aprende em grupo o elemento da cotidianeidade" 34 .

A nossa realidade exemplifica perfeitamente o modo como o fenômeno se manifesta: é difundido um discurso de medo no seio da sociedade, uma retórica que qualifica determinados indivíduos como potencialmente perigosos e que, por conta disso, devem merecer tratamento especial, legitimando-se arbitrariedades punitivas por parte das autoridades públicas, bem como a restrição de direitos e garantias individuais aos selecionáveis.

Com efeito, no território brasileiro, devido a um processo histórico de discriminação, o exercício do poder punitivo ainda é norteado pela noção de periculosidade apresentada por Michel Foucault: ${ }^{35}$

\footnotetext{
"toda a penalidade do século XIX passa a ser um controle, não tanto sobre se o que fizeram os indivíduos está em conformidade ou não com a lei, mas ao nível do que podem fazer, do que são capazes de fazer, do que estão sujeitos a fazer, do que estão na iminência de fazer"
}

\footnotetext{
${ }^{34}$ BATISTA, Vera Malaguti. O medo na cidade do Rio de Janeiro. Dois tempos de uma historia. $2^{\mathrm{a}}$ ed. Rio de Janeiro: Revan, 2009. p. 53.

${ }^{35}$ FOUCAULT, Michel. A verdade e as formas jurídicas. Rio de Janeiro: PUC/RJ e Nau Editora, 2001, pp.85-86.
} 
Trata-se, evidentemente, do que se convencionou chamar de direito penal do autor. Os indivíduos são identificados não pelo que fizeram, mas pela ameaça que representam. Aproxima-se, portanto, da lógica de "combate por periculosidade" nos moldes da teorização de Jakobs.

Assim, verificadas determinadas características e identidades (cor da pele, local que habita, nível de escolaridade, etc), identifica-se um criminoso em potencial, alguém que pode vir a cometer atos delituosos.

Note-se que Foucault apresenta o tema para justificar o sistema penal no século XIX, o que demonstra como essa tendência ainda permanece atual. De fato, no Brasil, a discriminação exercida sobre populações "potencialmente perigosas" é histórica, pode ser identificada desde a época colonial, seguindo-se durante a vigência do Império e, posteriormente, nos governos republicanos.

Como se pretende aqui demonstrar, ao longo do tempo, o estereótipo do criminoso brasileiro, via de regra, esteve associado à pobreza, aos que foram excluídos da vida política e econômica e, por decorrência disso, sempre representaram uma ameaça à ordem hierárquica estabelecida. Para tanto, faz-se necessário, em um primeiro momento, voltar ao passado e buscar, nos séculos anteriores, as origens desse discurso discriminatório.

\section{1 - CRIME E EXCLUSÃO SOCIAL: ABORDAGEM HISTÓRICA}

Em um país que traz como herança mais de 300 anos de escravidão, revela-se claro que o grande contingente de negros, mestiços e mulatos hoje existente se deveu a esse intenso movimento migratório que remonta à época do Brasil-colônia, e ao processo de miscigenação que se desencadeou a partir da chegada dos escravos. 
Durante o período colonial e o Império, determinados segmentos da sociedade brasileira tinham sua condição de cidadão amplamente renegada, sendo privados de todos os direitos básicos atribuídos ao ser humano enquanto ser social. Como é sabido, estes indivíduos, em sua grande maioria negros escravos, eram privados de liberdade, do direito ao voto e de qualquer meio de expressão cultural.

Diante das parcas condições de vida que lhes eram oferecidas, evidente que os riscos de retaliação existiam e, por isso, as elites econômicas desenvolveram com o passar dos anos mecanismos de repressão aos movimentos de resistência das classes vigiadas (negros, índios, mulatos, mestiços). É o que enuncia a historiadora e socióloga Vera Malaguti ${ }^{36}$ :

\footnotetext{
"A sociedade imperial escravocrata brasileira, rígida e hierarquizada como a colonial, precisava também de um medo desproporcional à realidade para manter violentas políticas de controle sobre aqueles setores que estavam potencialmente a ponto de rebelar-se e implantar "a desordem e o caos", tamanha a escala de opressão em que se encontravam."
}

Com a eclosão de uma série de revoltas populares durante o período regencial, como a sabinada, cabanagem, revolta dos malês e balaiada, a ameaça de insurreição negra se expande e, com isso, intensificam-se os esforços de neutralização e controle sobre as classes subalternas. A preocupação com a segurança é redobrada.

Segundo o historiador Sidney Chalhoub, é justamente no período imperial, na segunda metade do século XIX, durante operações policiais travadas para eliminação de habitações populares e epidemias na Corte, que é desenvolvido o conceito de classes perigosas. Perigosas porque pobres,

\footnotetext{
${ }^{36}$ BATISTA, Vera Malaguti. Op. Cit, p.30.
} 
por desafiarem as políticas de controle social no meio urbano e também por serem consideradas propagadoras de doenças ${ }^{37}$.

Para justificar o controle arbitrário exercido sobre essa parcela da população, diversas doutrinas discriminatórias foram suscitadas, em conformidade com as obras surgidas na Europa do século XIX, teorias estas que exerceram influência direta na política de segregação implementada no Brasil mesmo após o fim da escravidão.

A escravidão do passado, em especial a do negro, fora justificada por pensadores europeus a partir de teorias racistas. Baseadas em ideais eugênicos, estas afirmavam serem prejudiciais as misturas raciais, pois que da mistura das "raças" surgiriam enfermidades, doenças físicas e morais, comportamentos indolentes. Em suma, estaria justamente no contato com outras "raças" a origem dos perigos sociais. ${ }^{38}$

Esse viés discriminatório foi em muito reforçado pela divulgação da obra de Charles Darwin, “A Origem das Espécies”, em 1859. Conforme mencionado no primeiro capítulo deste trabalho, a teoria do processo evolutivo fora trazida para o campo das ciências sociais e utilizada para justificar o grau de inferioridade das classes subalternas, bem como dos povos dominados durante o neocolonialismo. O darwinismo social orientou a criação de conceitos como o da degenerescência da espécie, da procriação defeituosa, inferiorização da prole, etc.

Evidente que, por detrás dessas teorias racistas de cunho positivista, desenvolvidas por médicos psiquiatras, biólogos, criminólogos e outros estudiosos que atribuíam o status científico às suas conclusões, residia uma preocupação, um temor para com os povos oprimidos:

37 CHALOUB, Sidney. Cidade febril: cortiços e epidemias na Corte imperial. São Paulo: Companhia das Letras, 1996.

${ }^{38}$ COIMBRA, Cecília Maria Bouças. Direitos Humanos e criminalização da pobreza. Disponível na internet: http://www.slab.uff.br/images/Aqruivos/textos_sti/Cec\%C3\%ADlia\%20Coimbra/texto54.pdf. Acesso em 19 out 2015. 
"Se o medo na Europa do século XIX era o medo da revolução, no Brasil e na América Latina esse temor era acrescido pelo fim da escravidão, não só pelo fim da brisa, mas também pelas fantasias acerca do desfecho brutal da escravatura"39.

Como se sabe, o fim da escravidão no Brasil não dera ensejo ao desenvolvimento de políticas capazes de inserir a população pobre e, em sua maioria, negra, na sociedade da época. Na prática, os grandes contingentes de negros e pobres, ainda que livres da condição de mercadoria que antes detinham, continuavam a margem da sociedade, sendo tão-somente identificados a partir do risco que representavam para o país em processo de formação.

É nesse cenário que se desenvolvem no país movimentos higienistas e políticas de branqueamento da população brasileira, impulsionadas pelas doutrinas racistas que antes haviam justificado a escravidão e que, com a libertação dos escravos, passavam a justificar a manutenção de políticas de segregação social/racial. Coloca-se como metas o aperfeiçoamento da raça, em detrimento de negros e mestiços, que compunham a maioria da população pobre do país.

Nesse contexto, as reformas urbanas implementadas na cidade do Rio de Janeiro, capital da república à época, refletem o caráter excludente das políticas públicas do período, e o modelo de sociedade que se pretendia desenvolver a partir de então.

Tais modificações, realizadas sobretudo durante o governo do prefeito Pereira Passos (1902-1906), médico-sanitarista, caracterizaram-se pela

\footnotetext{
"abertura de ruas e grandes avenidas - como a Avenida Central, hoje Rio Branco - e a extinção de quiosques, casas de cômodos e cortiços. Torna-se urgente a tarefa de extinguir a imagem de um Rio antigo que era sinônimo, nos países europeus, de febre amarela, condições miseráveis e anti-higiênicas, transformando-o no símbolo de um Brasil novo e moderno. O centro da cidade,
}

${ }^{39}$ BATISTA, Vera Malaguti. Op. Cit. p.85 
densamente povoado por ex-escravos, operários e assalariados, é transformado com a construção de largas avenidas e novos e elegantes prédios" ${ }^{\text {"40 }}$.

Em razão deste processo, toda essa antiga população é compulsoriamente deslocada para as zonas suburbanas e encostas dos morros. Desse modo, outros ambientes passam a se desenvolver:

" os "territórios dos pobres", onde a miséria, a insalubridade, os pardieiros, as ruas mal traçadas e pavimentadas se fazem presentes. No Rio de Janeiro, as encostas dos morros - após a reforma de Pereira Passos, principalmente - são ocupadas pelos pobres; vale dizer, desde o início do século passado as "favelas" integram a complexa paisagem da cidade"

Aos poucos, reforça-se a imagem dos cortiços como local do crime. Esses territórios, caracterizados pelas habitações coletivas, passam a ser sinônimo de desorganização, ociosidade, ilegalidade, insalubridade e, portanto, de perigo. Com efeito, os habitantes pobres da capital, moradores dos morros (futuras favelas) já eram estigmatizados como "imorais", "poluidores" e "perigosos".

Nas décadas seguintes, o fenômeno se intensifica, especialmente por conta do crescimento das populações urbanas e dos movimentos migratórios para as grandes cidades em busca de melhores oportunidades. Em 1930, a prefeitura do Rio de Janeiro já se refere às possibilidades de remoção:

(...) são as favelas, uma das chagas do Rio de Janeiro, na qual será preciso, num dia muito próximo, levar-lhes o ferro cauterizador (...) a sua lepra suja a vizinhança das praias e os bairros mais graciosamente dotados pela natureza (...) A sua destruição é importante não só sob o ponto de vista da ordem social e da segurança, como sob o ponto de vista da higiene geral da cidade, sem falar da estética". ${ }^{41}$

\footnotetext{
40 COIMBRA, Cecília Maria Bouças. Direitos Humanos e criminalização da pobreza, p. 7. Disponível na internet: http://www.slab.uff.br/images/Aqruivos/textos_sti/Cec\%C3\%ADlia\%20Coimbra/texto54.pdf. Acesso em 19 out 2015.

${ }^{41}$ AGACHE, Alfred. Cidade do Rio de Janeiro: Remodelação, Extensão e Embelezamento. Paris: Foyer Brésilien, 1930.
} 
Permanece, portanto, um discurso higienista, que procura evitar o contato entre a população potencialmente perigosa e as demais pessoas. Nesse sentido, a eliminação das habitações coletivas traduz um imperativo de ordem social, segurança e higiene da cidade. Todos esses fatores, evidentemente, continuam a contribuir para que cada vez mais se associe o pobre/favelado ao crime. Reforça-se, ao longo do tempo, o estereótipo criminal.

Como se vê, o fenômeno de criminalização da pobreza, a criação da imagem do pobre criminoso tem as suas raízes no passado, na construção de uma sociedade excludente, mesmo com a libertação dos escravos. Resta, agora, demonstrar como esse estigma ainda se mantém.

\section{2 - ESTIGMATIZACÃO DO POBRE: PERMANÊNCIAS DO PASSADO}

Na realidade brasileira atual, não há como negar que esse processo de criminalização da pobreza ainda subsiste, mesmo que se modifique a retórica, bem como os polos de poder responsáveis pela difusão desses discursos de insegurança e instabilidade.

Conforme se passa a analisar, as associações entre crime e pobreza, entre criminoso e favela, surgidas no princípio do século passado, se adequam perfeitamente ao panorama contemporâneo. Para o presente tópico, oportuno destacar desde logo que:

(i) desde as últimas décadas do século XX e início do século XXI, novos atores detém presença marcante na ocorrência do fenômeno da seletividade punitiva, como os meios de comunicação de massa e o aparato repressivo da polícia militar, agências que desempenham papel importante na vigilância e neutralização das populações potencialmente perigosas. 
(ii) contrariamente às soluções segregacionistas e higienistas do passado, que excluíam as classes subalternas da vida nas cidades, com o tempo foram sendo adotadas soluções de caráter imediato, políticas de extermínio levadas a cabo primeiro pelos militares no poder (durante a ditadura), depois pela polícia militar, a partir da "redemocratização" do Estado.

(iii) com a intensificação do processo de formação do estereótipo criminal, identificando-se claramente os inimigos em potencial do Estado, desenvolveram-se doutrinas de Lei e Ordem, políticas de tolerância zero, ampliando-se a esfera de atuação do poder punitivo e, consequentemente, aumentando-se o nível de arbitrariedades cometidas pelo poder público.

(iv) com o tempo, a violência passou a ser o marco característico das grandes metrópoles do país, fenômeno que não mais causa espanto, mas que constitui fato banal. Evidente que, nessas estatísticas, o número de vítimas que se adequam ao estereótipo criminal compreende a maioria.

Toda essa mudança de perspectiva quanto ao trato para com os inimigos/perigosos no Brasil se deu a partir da ditadura militar e se seguiu com a redemocratização do Estado. Deve-se, então, abordar o fenômeno de fortalecimento do poder punitivo no regime de exceção para, em seguida, demonstrar como, mesmo superada a ditadura, as práticas violentas permaneceram, com os processos de criminalização, controle e extermínio de populações excluídas e vulneráveis ${ }^{42}$.

Nesse contexto, três fatores mostraram-se determinantes para a consolidação do estereótipo criminal e justificação de políticas repressivas: o fortalecimento da mídia e do seu poder de influência, o desenvolvimento de políticas antidrogas e de um processo de demonização das favelas.

\footnotetext{
42 DORNELLES, João Ricardo. Direitos Humanos, violência e barbárie no Brasil: uma ponte entre o passado e o presente In: Bethania Assy; Carolina Campos Melo; João Ricardo W. Dornelles; José Maria Gómez. (Org.). “Direitos Humanos, Justiça, Verdade e Memória” - $1^{\text {a }}$ ed. Vol. 1. Rio de Janeiro: Lumen Juris Editora, 2012.
} 


\subsection{1 - Da ditadura militar à redemocratização}

A ditadura militar brasileira (1964-1985), como já é de conhecimento público, caracterizou-se pelas violações sistemáticas de direitos humanos. Neste período, o Estado brasileiro fora responsável pela perpetração de diversas arbitrariedades: execuções sumárias, desaparecimentos forçados, emprego de tortura, etc.

Durante o regime de exceção, foram criados uma série de órgãos e serviços de inteligência a cargo dos militares, com a finalidade de vigiar e reprimir movimentos ditos "subversivos". Para além da mera ameaça de subversão à ordem, havia um interesse claro em concretizar um projeto econômico excludente:

O golpe militar de 1964, no Brasil, representou a instalação de uma nova forma de dominação política que possibilitou o desenvolvimento de um modelo de modernização capitalista dependente e excludente. Além da grande repressão política e ideológica sobre o conjunto da população - atingindo principalmente as classes populares, os militantes de esquerda, as lideranças sindicais e de movimentos sociais -, o regime imposto em 1964 possibilitou a criação das condições e estímulos para a entrada de capitais estrangeiros, com a política de contenção dos níveis salariais (arrocho salarial), de benefícios aos grandes oligopólios em detrimento das pequenas e médias empresas, beneficiando o processo de concentração ampliada do capital. ${ }^{43}$

Nesse sentido, o governo dos militares não rompe com a lógica de exclusão social do passado, reprimindo duramente movimentos sociais, bem como qualquer outro tipo de manifestação de insatisfação para com as políticas implementadas.

Durante a ditadura militar, dado o caráter conservador-ideológico do sistema de governo, o a figura do inimigo recai, principalmente, sobre o manifestante comunista e os integrantes de grupos de esquerda. Para

\footnotetext{
${ }^{43}$ DORNELLES, João Ricardo. Idem, p.437.
} 
justificar os excessos cometidos pelo Estado, cria-se um discurso de combate às organizações comunistas e aos comportamentos de subversão à ordem pública, impondo-se às autoridades deter os resistentes que impedem o país de caminhar para o progresso:

(...) as práticas de desrespeito aos direitos humanos e de violência generalizada foram acompanhadas de justificativas sobre a segurança nacional, a ordem, o progresso e o desenvolvimento. A Doutrina de Segurança Nacional e de Desenvolvimento foi a base ideológica do regime. As perseguições políticas levaram à organização de um grande aparato de repressão que se expressou nas práticas de terror de Estado." 44

No discurso emanado do poder público e difundido mediante propaganda ideológica, estigmatiza-se o jovem com ideais comunistas. $\mathrm{Na}$ prática, evidentemente, a repressão atinge todos os setores da população que, seja de que modo for, manifestam seu inconformismo: estudantes, líderes sindicais, operários, grupos guerrilheiros, trabalhadores rurais, etc. Com efeito, a referência a supostas inclinações de caráter ideológico dos manifestantes é mera retórica hábil a dar carta branca para as autoridades públicas praticarem todo tipo de arbitrariedade.

Aqui se identifica, sem dúvida alguma, o fenômeno do direito penal do inimigo: determinados indivíduos passam a ser visualizados não pelo caráter de cidadão que ostentam, mas pela ameaça que representam ao governo estabelecido. Por meio da criação de um discurso de medo totalmente desproporcional à realidade, segundo o qual a iminência de uma sublevação dos grupos comunistas pode levar o país à desordem, justificase o fortalecimento do aparato repressivo do Estado, com o aumento do número de prisões, execuções, torturas e desaparecimentos.

Por detrás dos discursos, identifica-se os reais objetivos de uma política de combate: com o incremento do poder punitivo e da repressão, é possível manter o controle sobre as estruturas sociais, a hierarquização da sociedade permanece como antes, bem como as desigualdades sociais nela

\footnotetext{
${ }^{44}$ DORNELLES, João Ricardo. Idem, p. 438.
} 
existentes. Conclui-se, então, que o sistema penal fora a principal base, o que sustentou os militares no poder durante este período.

\subsection{2 - Drogas, tráfico e favelas}

Em 1985, o regime militar, que há tempos vinha se desgastando e sofrendo pressões internacionais, é desmantelado. Contudo, mesmo após a restauração da democracia no país, o poderio bélico posto a serviço da ditadura continua a ser amplamente utilizado:

\footnotetext{
"Em grande parte, este aparato repressivo e as práticas terroristas utilizadas pelo regime militar continuaram, após 1985, nas ações policiais contra as populações mais pobres (...) no Brasil, a volta à institucionalidade democrática, em meados dos anos 1980 não significou uma diminuição significativa nas violações sistemáticas e massivas de direitos humanos. Ao contrário, o que se verificou foi um aumento significativo dos casos de violações, principalmente atingindo os contingentes mais pobres da população". ${ }^{45}$
}

Como já havia sido adiantado no primeiro capítulo deste trabalho, as violações sistemáticas de direitos humanos que passam a ser praticadas contra populações pobres podem ser explicadas a partir de um processo de demonização do tráfico e uso de drogas. Nas palavras de Eugenio R. Zaffaroni, após a dissolução da URSS e dos regimes militares, “tornou-se necessário eleger outro inimigo para justificar a alucinação de uma nova guerra e manter níveis repressivos elevados. Para isso, reforçou-se a guerra contra a droga.",46

Tratou-se, portanto, de uma política moralizante difundida pelos Estados Unidos e que se propagou por toda a América Latina. Com o fim da Guerra Fria, era preciso encontrar uma forma de justificar a intervenção americana no plano internacional:

\footnotetext{
${ }^{45}$ DORNELLES, João Ricardo. Idem, p. 438-439.

${ }^{46}$ ZAFFARONI, E. Raul. Op. Cit. p.51.
} 
"O vácuo que a queda progressiva da ameaça comunista deixava seria gradativamente ocupado por um novo perigo identificado pelo governo norteamericano: o narcotráfico." ${ }^{47}$

Assim, influenciado por este discurso, todo o Cone Sul do continente americano "sancionou leis antidroga muito parecidas, em geral por pressão da agência estadunidense especializada, configurando uma legislação penal de exceção análoga à que antes havia sido empregada contra o terrorismo e a subversão. "48

No Brasil, como era de se esperar, as atenções do sistema penal passam a se voltar contra a figura do traficante de drogas, que é elevado à condição de principal inimigo público. Promulgada a Constituição Federal de 1988, o documento se encarregou de equiparar o tráfico de drogas a crime hediondo (art. $5^{\circ}$, XLIII). Editada a Lei de Crimes Hediondos (Lei ${ }^{\circ}$ 8.072/90), são restringidas uma série de garantias processuais e penais aos acusados da prática de delitos ali compreendidos: exigência de cumprimento da pena em regime integralmente fechado, impossibilidade de concessão de liberdade provisória, dentre outras.

As drogas, portanto, passam a ser tratadas como questão de segurança nacional, exigindo atenção redobrada por parte das agências executivas do poder punitivo (policiais, agentes carcerários, juízes, etc). Dentro desse contexto, estende-se a vigilância sobre as denominadas "áreas de risco", confere-se uma margem de atuação mais ampla à primeira dessas agências a agir, qual seja, a polícia.

Com o tempo, evidentemente, a representação do criminoso passa a ser publicamente atribuída à figura de um traficante de drogas, imagem que é naturalmente apropriada pelo senso comum. O rótulo de periculosidade que antes recaia sobre a figura do "comunista" passa a ser ostentado pelo traficante de drogas:

\footnotetext{
${ }^{47}$ RODRIGUES, Thiago. Narcotráfico: uma guerra na guerra. São Paulo: Desativo, 2003. p.74.

${ }^{48}$ ZAFFARONI, E. Raul. Op. Cit. p.52.
} 
"O "traficante", a partir dos anos 80, passa a ser utilizado como termo estigmatizante capaz de reduzir a compreensão acerca de um indivíduo. Se nos anos 70 o "comunista" era o responsável por "degustar criancinhas" em nosso país, hoje o "traficante" é responsável até por estimular o surgimento de favelas." 49

Dentro desse fenômeno, com o passar dos anos, reforça-se o estereótipo do criminoso como alguém que é pobre, preto e favelado. Isso porque, como a face do traficante "vai se consumando na figura de um jovem negro, funkeiro, morador da favela e próximo do tráfico" ${ }^{\circ 0}$, cria-se naturalmente um intercâmbio entre crime e pobreza.

O problema reside justamente nessa falácia: "ao afirmar que o criminoso é, caracteristicamente, pobre, abre-se facilmente a possibilidade de inverter os termos da equação, para dizer: o pobre é, caracteristicamente criminoso". 51

Influenciadas por uma visão do senso comum de que o pobre é potencialmente perigoso, as políticas de segurança das grandes cidades do país priorizam a vigilância e controle sobre essa parcela da população.

“Assim, ao pararem pessoas nas ruas ou abordarem-nas nos botequins, os policiais as selecionarão de acordo com a ideia que possuem a respeito de quem é criminoso" 52 . Adequando-se o indivíduo ao estereótipo construído socialmente (pobre, negro, favelado), mais propício está ele a cometer crimes e, por conta disso, a merecer tratamento diferenciado. Confirma-se, cada vez mais, a noção de periculosidade que remonta ao século XIX, sendo esta classe de sujeitos julgada a partir não do que fizeram, mas pelo que representam.

\footnotetext{
${ }^{49}$ ZACCONE, Orlando. Os acionistas do nada: quem são os traficantes de drogas. $3^{\mathrm{a}}$ Ed. Rio de Janeiro: Revan, 2007. p.58.

${ }^{50}$ Idem, p. 21.

51 THOMPSON, Augusto. Quem são os criminosos? 2a Ed. Rio de Janeiro: Lumen Juris, 2007. p.64.

52 Idem. p. 65.
} 
Dentro dessa realidade, não são poucos os episódios em que atuações policiais equivocadas se fundamentam única e exclusivamente na adequação do suspeito em potencial ao estereótipo criminal dominante no Brasil.

Neste ano de 2015, uma ação policial ocorrida no bairro da Gávea, no Rio de Janeiro, demonstrou com exatidão qual a face do criminoso: jovens pobres e negros, moradores da favela da Rocinha, iniciaram uma briga em um coletivo e, após saltarem e continuarem a confusão na rua, foram detidos por policiais civis, que pensavam se tratar de um assalto. $\mathrm{O}$ ato movimentou a região e chamou a atenção de alguns freqüentadores do shopping localizado em frente ao local que, imbuídos por um sentimento de ódio, pediram o justiçamento dos adolescentes, afirmando se tratar de "raça ruim" e dizendo que "ninguém agüenta mais". Um dos transeuntes chegou a agredir um dos jovens no momento em que eles já haviam sido imobilizados pelos agentes policiais. ${ }^{53}$

Levados para a delegacia, os jovens foram liberados depois da revelação de que tudo havia sido um engano e que a ação policial não tinha qualquer fundamento. Nesse contexto, simbólico fora o depoimento da mãe de um dos garotos ao deixar a delegacia: "chegou e simplesmente agrediu. Agrediu por quê? Porque é um morador da favela, é preto, ai é muito fácil falar. É uma briga de colégio, não foi assalto. Quem nunca brigou?"

De fato, muito improvável imaginar que a polícia teria o mesmo comportamento se os jovens em confronto fossem de classe média. Não há como negar que o estereótipo criminal influenciou toda a operação policial, a atitude do agressor, bem como a opinião de todos os que pediram a morte dos garotos.

53 Disponível em: http://g1.globo.com/rio-de-janeiro/noticia/2015/06/menor-e-agredido-porpedestre-em-frente-shopping-no-rio-veja-video.html e http://odia.ig.com.br/noticia/rio-dejaneiro/2015-06-25/pedestres-pedem-morte-de-jovens-negros-que-brigavam-na-zona-sul.html). Acesso em 10 de out 2015. 
Aliás, movida por este estereótipo, vem a polícia exercendo um controle flagrante sobre as populações pobres nessas últimas décadas, apertando a vigilância sobre os indivíduos avaliados como "mais propensos a desrespeitar as leis" ${ }^{\circ 4}$ :

“(...) o sistema penal exercita um poder de vigilância disciplinar, de uso cotidiano, nas áreas carentes, seja restringindo a liberdade de ir e vir naquelas comunidades, através de prisões para averiguação, ou restringindo reuniões e o próprio lazer das pessoas, como na proibição dos "bailes funks", que a pretexto de reprimir a "apologia ao narcotráfico", traduz o poder de controle exercido sobre as populações pobres" $"$.

A isso se adiciona uma visão das favelas como "área de risco", favorecendo todo tipo de discriminação contra os seus habitantes. Em sua obra "O medo na cidade do Rio de Janeiro", a socióloga Vera Malaguti Batista trabalha com editoriais de periódicos locais para explicitar a imagem reproduzida pela sociedade a respeito desses territórios populares. Vejamos alguns trechos:

A favela aparece nos editoriais como lócus do mal e dissolutora de fronteiras: (...) Os cidadãos que moram na cidade que está no mapa já não suportam submeter-se à outra população, armada, em continua expansão, acasalada sob o guarda-chuva protecionista dos traficantes, dos bicheiros e dos políticos populistas. - (“A ameaça das favelas", Jornal do Brasil, 5 de fevereiro de 1994) ${ }^{56}$

(...) Esses bandidos se animalizaram. Eles são animais. Não podem ser compreendidos de outra maneira. Por isso os confrontos não podem ser civilizados. Essa gente não tem que ser tratada civilizadamente. Têm que ser tratados como animais. (Marcello Alencar, governador do estado do Rio de Janeiro, em rede nacional de TV, programa Jornal da Manchete, TV Manchete, 11 de maio de 1995). ${ }^{57}$

(...) "Já está mais do que na hora de nossas autoridades se mobilizarem e, com o apoio da sociedade, providenciarem a remoção da favela. (...) Se as autoridades, por demagogia, desinteresse ou sucumbindo às pressões de ONG's defensoras de marginais nada fizerem, a situação tende a piorar. Não queremos uma reedição da ficção, como no filme "Parque dos Dinossauros", onde cercas eletrificadas separavam seres humanos de bestas. O final do filme nós já sabemos". (Carlos

\footnotetext{
54 THOMPSON, Augusto. Op. Cit, p. 65.

${ }^{55}$ ZACCONE, Orlando. Op. Cit, p.30-31.

${ }^{56}$ BATISTA, Vera Malaguti. Op. Cit, p.111.

${ }^{57}$ Idem, p.113-114.
} 
Fabio Penna, leitor de O Globo, Carta dos Leitores, 10 de janeiro de 1998, p. 6)" 58

Curioso notar que, passados mais de 100 anos desde o início de um processo de segregação social para com os moradores das encostas e cortiços, tal como mencionado previamente neste trabalho, os mesmos preconceitos que existiam naquele período ainda são reproduzidos na atualidade:

"O delinqüente é identificado pelo fato de ser favelado antes de sê-lo pelo ato de que é acusado. Na favela habita boa parte das populações pobres dos grandes centros urbanos e que de forma alguma é composta de delinqüentes. Não se pode negar que a maior parte dos presos procede de periferias, favelas, bairros pobres, mas a sutileza da argumentação está no fato de que isto não significa que haja uma relação necessária e natural entre ser favelado e ser delinqüiente: a relação é social. Na sua grande maioria, os moradores das favelas não são delinqüentes, mas são tratados enquanto tais pela policia e pela justiça." 59

Aos poucos, a demonização das favelas por parte da sociedade passa a justificar uma atuação mais repressiva contra a população local.

"Com a lógica da guerra, são admitidos os "excesso inevitáveis", o cerco das favelas, o tratamento das áreas populares como território inimigo, hostil e perigoso, a desumanização dos moradores destas áreas, através de perseguições, torturas, detenções arbitrárias e sem mandato judicial, assassinatos, etc. ${ }^{60}$,

Nesse cenário, assimila-se a imagem do crime, determinados sujeitos, identificáveis por características físicas e sociais específicas, são tratados pelos demais apenas pelo caráter perigoso que representam. Aos poucos, determinadas garantias constitucionais e penais comuns lhes são restringidas (direito à privacidade, ao devido processo legal, à liberdade, etc) e legitimam-se arbitrariedades contra esta classe de pessoas.

Como se vê, mantém-se, mesmo após a derrubada do regime militar, a mesma lógica da guerra que o movimentava. Agora, o inimigo declarado é o traficante de drogas. Nesta guerra diária, "o traficante estigmatizado, ou

\footnotetext{
${ }^{58}$ Idem, p.115.

${ }^{59}$ RAMALHO, José Ricardo. O mundo do crime: a ordem pelo avesso. Rio de Janeiro: Graal, 1979, p.169.

${ }^{60}$ DORNELLES, João Ricardo. Op. Cit, p.445.
} 
seja, aquele que apresenta uma relação entre o atributo presente na venda de substância entorpecente e o estereótipo do criminoso (preto, pobre, favelado) é um verdadeiro passe livre para as ações penais genocidas ${ }^{61}$."

Não raro lemos notícias em que determinados indivíduos são baleados ou mortos em comunidades em confronto com a polícia, e que apresentavam suspeitas de envolvimento com o tráfico de drogas. Trata-se do dia-a-dia policial. Nesse contexto de guerra constante, ampliam-se os números da violência.

\section{3 - OS DISCURSOS MIDIÁTICOS}

Conforme previamente abordado no primeiro capítulo, para que a vigilância, a contenção e eventual eliminação dos inimigos possam ser legitimadas no seio da sociedade, faz-se necessário difundir um discurso de emergência apto a justificar o aumento do poder punitivo, retórica pautada na ameaça desproporcional que determinados indivíduos representam à ordem estabelecida. "A difusão do medo é mecanismo indutor e justificador de politicas autoritárias de controle social” $"$.

No Brasil, os meios de comunicação desempenham papel fundamental no processo de seleção e perpetuação da figura do inimigo. A mídia alcança um poder desmedido e destrutivo no Brasil dada a brutal concentração dos veículos comunicativos nas mãos de alguns grandes empresários. Além disso, o avanço das tecnologias da informação permite

\footnotetext{
${ }^{61}$ ZACCONE, Orlando. Op. Cit, p.58.

${ }^{62}$ BATISTA, Vera Malaguti. Op. Cit. p. 23.
} 
que as mensagens propagadas por jornais e televisores alcance praticamente a totalidade da população. ${ }^{63}$

Como as corporações de mídia estão organizadas enquanto empresas, elas também buscam o lucro acima de tudo - para si e para as empresas associadas. Sendo assim, não há como exigir desses canais de comunicação uma postura equilibrada. Essa característica, portanto, se torna determinante na elaboração das mensagens que projeta para a população. ${ }^{64}$

Na prática, não se deve ler uma notícia de jornal ou assistir a um noticiário na televisão sem se questionar acerca da procedência das informações, sem buscar compreender as razões ocultas para aquele tipo de abordagem jornalística. É preciso, portanto, proceder a uma interpretação ampla daquilo que nos é fornecido.

Inclusive porque, no nosso país, não há como negar que as corporações midiáticas mais influentes detém uma inspiração ideológica conservadora, podendo ser muitas vezes identificados os interesses por detrás das mensagens propagadas.

No tocante ao sistema penal, a mídia possui influência direta na adoção e avaliação das políticas de segurança pública levadas a cabo nas grandes metrópoles. Trata-se de uma característica comum entre países do denominado "capitalismo tardio" (países de terceiro mundo latinoamericanos):

\footnotetext{
"Uma importante característica dos sistemas penais do capitalismo tardio é a sua vinculação com a mídia. Nilo Batista afirma que, no presente, assistimos à ultrapassagem da sua função comunicativa para a executivização dessas agências de comunicação social do sistema penal". ${ }^{65}$
}

\footnotetext{
63 SALLES, Marcelo. Comunicação e Controle Social, In Revista de Política e Cultura da ADUFF: Violência, Mídia e Criminalização da Pobreza, Ano I n², 2008. Disponível em: http://www.aduff.org.br/publicacoes/200812_classe_2.pdf. Acesso em 05 de Nov 2015.

${ }^{64}$ Idem. Ibidem.

${ }^{65}$ BATISTA, Vera Malaguti. Op. Cit. p.106.
} 
De fato, os meios de comunicação têm o papel determinante de difundir uma retórica de medo no todo social, contribuindo para a criação de uma constante sensação de insegurança, legitimando-se o fortalecimento do poder punitivo, o cometimento de arbitrariedades por parte da polícia e o aumento da vigilância sobre populações pobres. Nesse cenário, o estereótipo do criminoso é reforçado, os preconceitos já existentes são revigorados.

A socióloga Vera Malaguti afirma que:

"a grande política social da contemporaneidade neoliberal é a política penal. A qualquer diminuição do seu poder os meios de comunicação de massa se encarregam de difundir campanhas de lei e ordem que aterrorizam a população e aproveitam para se reequipar para os "novos tempos." 66

Essa pressão midiática, ao gerar uma sensação de vulnerabilidade, cria o contexto para que sejam implementadas "políticas criminais com derramamento de sangue", reforçam a ode ao extermínio e declaram guerra aos inimigos públicos. ${ }^{67}$

Dentro desse contexto, observa Dornelles que:

"esse discurso conservador, no senso comum das classes média e alta, acaba por consolidar uma espécie de "fascismo social", com demandas por recrudescimento penal, por aumento das penas e até mesmo por retrocessos no que se refere ao reconhecimento de direitos das populações mais pobres excluídas da sociedade." 68

Os meios de comunicação, sem sombra de dúvidas, representam o principal mecanismo indutor e justificador dessas políticas repressivas, por se tratarem do canal necessário entre o sistema penal e a sociedade. No Brasil, é a mídia que direciona, é ela que produz o conhecimento do senso comum.

\footnotetext{
${ }^{66}$ Idem. p. 33.

${ }^{67}$ BATISTA, Nilo. "Política criminal com derramamento de sangue”. In: Revista Brasileira de Ciências Criminais, ano 5, $\mathrm{n}^{\circ}$ 20, outubro-dezembro de 1997. São Paulo: IBCCRIM/Revista dos Tribunais, 1997

${ }^{68}$ DORNELLES, João Ricardo. Op. Cit, p.445.
} 


\section{4 - A SELETIVIDADE DA JUSTIÇA PENAL}

Construído o estereótipo do criminoso como alguém representante das classes inferiores, identificando-se a periculosidade com base em critérios físicos (aparência e cor da pele) e sociais (pobre, favelado, baixa escolaridade, eventualmente desempregado, etc), convém agora analisar como essa imagem do crime repercute, para além do senso comum, na apreciação dos operadores do sistema penal.

De imediato, importante ressaltar que não há independência prática entre o trabalho da polícia e o do Poder Judiciário, justamente porque os juízes têm seu âmbito de cognição delimitado em muito pelas investigações policiais, pelos inquéritos policiais que lhes são fornecidos. Assim, para que os magistrados desempenhem o seu papel de maneira eficiente, é preciso que a polícia tenha previamente trabalhado com seriedade.

Nesse processo, da prática do delito à condenação do autor há um obrigatório caminho a ser percorrido, o qual se caracteriza pelas seguintes etapas: (i) o relato do fato à policia; (ii) o registro do fato; (iii) o desenvolvimento de investigações; (iv) a instauração de um inquérito a partir das investigações; (v) a propositura da ação penal pelo Mistério Público; (vi) a condenação do acusado pelo Poder Judiciário; (vii) o cumprimento efetivo da pena. ${ }^{69}$

Augusto Thompson, ao especificar minuciosamente cada uma dessas fases, aponta como, na prática, há uma discrepância entre os fatos típicos praticados no mundo real e aqueles que levam concretamente a uma condenação e execução de uma pena ao responsável.

\footnotetext{
${ }^{69}$ THOMPSON, Augusto. Quem são os criminosos? $2^{\mathrm{a}}$ Ed. Rio de Janeiro: Lumen Juris, 2007. p.3.
} 
Trata-se do fenômeno da cifra oculta da criminalidade, o qual, nas palavras da criminológa Lola Anyar de Castro, se caracteriza pela diferença entre a criminalidade real e a criminalidade aparente, havendo uma enorme quantidade de casos que jamais serão conhecidos pela polícia ${ }^{70}$.

Thompson, analisando essas fases, demonstra como o estereótipo criminal e a condição social do acusado contribuem para que a maior parte dos sujeitos efetivamente condenados pela prática de crimes sejam negros e pobres, dada a maior visibilidade das infrações que cometem, a incapacidade de se beneficiarem de corrupção ou prevaricação dos policiais e o fato de estarem mais suscetíveis ao cometimento de arbitrariedades.

De fato, a população mais pobre transita mais por espaços públicos, necessita dos serviços comuns para viver (moradias, transportes, hospitais, etc), estando mais próximos da vigilância policial. Além disso, dada toda a facilidade de acesso e a ausência de privacidade característica das habitações populares (favelas), o controle exercido sobre seus atos é extremamente rigorosa.

Ademais, a carência de recursos financeiros impossibilita essa parcela da população de se beneficiar de corrupção, fenômeno que, como já é de conhecimento público, é muito comum na prática policial. Não menos relevante é o fato de que, na grande maioria das vezes, por conta da ausência de verba, os acusados encaminhados à delegacia não estão acompanhados por advogado, o que pode impulsionar o emprego de violência por parte dos agentes, intensificar a pressão sobre eles e viciar eventuais depoimentos.

Por fim, não há duvidas de que, dentre todos esses fatores discriminadores, o mais importante é justamente o amoldamento do sujeito ao estereótipo de criminoso já difundido pelo senso comum e reforçado pelos meios de comunicação.

${ }^{70}$ ZACCONE, Orlando. Op. Cit, p.18. 
Com efeito, releva notar que a representação do delinquiente não influencia apenas o trabalho da polícia (primeira agência do Estado a atuar e que condiciona o trabalho das demais), como também dos demais atores da justiça penal.

Em obra na qual se dedica ao estudo das drogas e da criminalização da juventude, Vera Malaguti identifica nas palavras de médicos psiquiatras, oficiais de justiça, assistentes sociais, promotores, juízes, dentre outros, uma visão discriminatória, carregada de preconceitos:

\begin{abstract}
"Uma assistente social do Instituto Padre Severino afirma em seu relatório de estudo de caso, em 1988 (!): "O local onde reside - área favelada - propicia seu envolvimento com pessoas perniciosas à sua formação moral”. (...) Um oficial de justiça, também em 1988, justifica a não entrega de uma intimação: "Área de difícil acesso e que por certo porá em risco tantos quantos ali penetrarem, ${ }_{71}$ povoada de malfeitores, todos altamente temidos pelos moradores da localidade"

"O setor de psiquiatria concentra seus diagnósticos num senso-comum construído sobre preconceitos. A função de criar 'corpos dóceis' aparece sempre que há sinal de rebeldia. M.A.O.B., morador do Morro de São Carlos, detido em $78 \mathrm{com}$ 4,53g. de maconha, recebe do Serviço de Liberdade Assistida o seguinte Relatório psicossocial: 'Projeta suas dificuldades e deficiências no meio ambiente, disso resultando ideias de que é prejudicado e injustiçado. O ideal seria que este menor continuasse o tratamento por longo período, em face das características da personalidade, muito suscetíveis a reincidências". ${ }^{72}$
\end{abstract}

Dos extratos, vê-se como toda a argumentação dos agentes envolvidos é carregada de interpretações subjetivas e preconceituosas acerca das favelas e dos seus moradores, viciando a imagem que detém dos acusados, tidos como criminosos em potencial.

O Poder Judiciário não foge à regra. Na prática processual penal, encaixando-se o acusado ao perfil de criminoso reproduzido pela sociedade, a possibilidade de condenação é naturalmente maior, sabendo-se que, como analisado previamente, já fora há tempos assimilada a ideia de que há um intercâmbio entre crime e pobreza.

\footnotetext{
${ }^{71}$ BATISTA, Vera Malaguti. Difíceis ganhos fáceis: drogas e juventude pobre no Rio de Janeiro. $2^{a}$ ed. Rio de Janeiro: Revan, 2003. (Pensamento criminológico; v.2) p. 117.

72 Idem. Ibidem.
} 
Essa provável condenação ganha contornos ainda mais evidentes se o sujeito (pobre, negro, favelado) já apresenta antecedentes criminais, o que vem para atestar que, de fato, se trata de um criminoso:

\begin{abstract}
“(...) mesmo sem dispormos de informações convincentes acerca da prática, por parte de dado individuo, de um fato preciso, contemplado como típico pela lei penal, reconhecê-lo-emos como delinqüente se: pertencendo à classe inferior - o que é apurável através das indicações mais visíveis relativas à cor (preto ou mulato), aspecto físico (falhas nos dentes, mãos e pés grandes, feições abrutalhadas, olhar obliquo), baixa escolaridade (linguagem pobre, pejada de gírias), morador em favela, membro de família desorganizada ou sem família, sem emprego ou subemprego - apresenta registros policiais. Os dois fatores são vistos como elementos de um mesmo circuito, em que o primeiro alimenta o segundo, o qual serve de feedback para aquele, que, fortalecido, realimenta o outro e assim por diante." ${ }^{.73}$
\end{abstract}

Pois bem, diante dessa constatação, importante ilustrá-la com um exemplo recente, o qual é mais do que esclarecedor. Nessa discussão acerca do atuar discriminatório da justiça penal, não há como não lembrar do caso do morador de rua Rafael Braga, preso no Rio de Janeiro por policiais em junho de 2013, no contexto das manifestações políticas realizadas pela população em todo o país. ${ }^{74}$

O rapaz foi encaminhado à delegacia pelos agentes por portar duas garrafas de plástico, uma com água sanitária e outra com álcool. Assim, foi denunciado por porte de material explosivo e, posteriormente, condenado a cinco anos de prisão. Mesmo tendo o laudo do Esquadrão Antibomba da Coordenadoria de Recursos Especiais apontado que o material apresentava "ínfima possibilidade de funcionar como coquetel molotov" e, portanto, aptidão mínima de incêndio, ele fora condenado pela mera presença de etanol em uma delas.

A despeito de todas as evidências contrárias que pautam a conduta pela qual fora incriminado, o rapaz se adequava perfeitamente ao

\footnotetext{
73 THOMPSON, Augusto. Op. Cit, p.68.

74 Disponível em: http://g1.globo.com/rio-de-janeiro/noticia/2014/08/morador-de-rua-esperaapelacao-apos-ser-preso-em-protesto-no-rio-em-2013.html http://www.cartacapital.com.br/sociedade/justica-decide-manter-prisao-de-morador-de-rua-quecarregava-pinho-sol-e-agua-sanitaria-4961.html. Acesso em 19 de out de 2015.
} 
estereótipo do criminoso difundido pelo senso comum: é negro, pobre, morador de rua. Além disso, para confirmar a presunção de culpa já evidenciada pela sua imagem natural, os antecedentes criminais: Rafael apresentava duas condenações por roubo já cumpridas integralmente.

Portanto, nesse caso, difícil vislumbrar que o magistrado tenha sido motivado pela análise da conduta do rapaz. Ao que tudo indica, foram determinantes para a decisão a sua adequação ao estereótipo criminal e a existência de registros em seu nome.

Não é de se espantar, então, que a maior parte da população carcerária do Brasil seja formada por negros e pobres. Dentre esses encarcerados, o número de jovens também é alarmante, assim como o de presos provisórios (sem condenação).

Portanto, diante da forma efetiva de funcionamento do sistema penal e do exercício discriminatório das agências do Estado dentro desse processo, conclui-se que a justiça penal é, de fato, seletiva. A sua maior clientela é o negro pobre.

Constatado esse atuar discriminatório, faz-se necessário indagar se há na legislação ordinária institutos hábeis a conferir ao magistrado essa possibilidade de impor uma visão preconceituosa, de tratar determinados indivíduos através de um enfoque que nada mais é do que expressão do fenômeno do direito penal do inimigo: o sujeito é identificado a partir do seu perigo em potencial, legitimando-se arbitrariedades e justificando-se uma política de contenção por parte do Estado.

Com efeito, analisa-se, a partir de agora, dois institutos especificamente: a decretação de prisões preventivas para garantia da ordem pública e a alocação de presos no regime disciplinar diferenciado. 


\section{CAPÍTULO 3 - A DECRETAÇÃO DE PRISÕES PREVENTIVAS PARA A GARANTIA DA ORDEM PÚBLICA}

As prisões preventivas no Brasil representam, sem dúvida, um claro exemplo em que o fenômeno do direito penal do inimigo se manifesta. $\mathrm{Na}$ prática, o seu caráter de proteção ao inquérito/processo é distorcido, transformando-se a medida em um grande mecanismo de neutralização de indivíduos potencialmente perigosos, acusados do cometimento de infrações penais.

Como os números mostram, a excepcionalidade da medida deixou de caracterizá-la há tempos, dada a banalização do decreto prisional, sobretudo quando o acusado se adequa ao perfil criminal construído pela sociedade e meios de comunicação.

Para melhor explicar essa realidade, importante apresentar primeiramente no que consiste essa modalidade prisional, sua natureza, características e fundamentos, analisando-se a Constituição Federal e a legislação infraconstitucional atinente ao tema.

\section{1 - A INSTRUMENTALIDADE DA PRISÃO PROVISÓRIA}

A prisão preventiva é uma modalidade de prisão cautelar. Como medida cautelar que é, tem por objetivo prevenir a ocorrência de danos enquanto não encerrado o processo penal. Trata-se, portanto, de um provimento de caráter instrumental, servindo para resguardar a eficácia da própria tramitação processual.

A cautelaridade da medida pode ser facilmente identificada da leitura dos dispositivos constitucionais aplicáveis ao tema. Vejamos, pois, o teor do art. $5^{\circ}$, incisos LVII e LXI da Constituição Federal de 1988: 
LVII - ninguém será considerado culpado até o trânsito em julgado de sentença penal condenatória;

LXI - ninguém será preso senão em flagrante delito ou por ordem escrita e fundamentada de autoridade judiciária competente, salvo nos casos de transgressão militar ou crime propriamente militar, definidos em lei; (grifou-se)

Como se vê, o art. $5^{\circ}$, LVII consagra o princípio da presunção da inocência, o qual impõe como regra a liberdade do acusado durante todo o processo penal. Somente é possível considerar o réu culpado e restringir a sua liberdade após o trânsito em julgado da sentença penal condenatória.

$\mathrm{O}$ art. $5^{\circ}, \mathrm{LXI}$, por sua vez, prevê a possibilidade de prisão mediante ordem escrita e fundamentada da autoridade judiciária competente. Tratase, evidentemente, de autorização dada pela Constituição para a decretação de prisões preventivas.

No entanto, o dispositivo deve ser interpretado em conjunto com o inciso LVII, que garantiu ser a liberdade do acusado a regra no processo penal. Assim, ainda que autorizada pela Lei Maior, a medida tem caráter excepcional, somente podendo ser adotada mediante decisão judicial concretamente fundamentada.

Da interpretação conjunta de ambos os dispositivos constitucionais, percebe-se, portanto, que o instituto:

jamais poderá colocar o acusado em uma posição jurídica que o faça presumir culpado pela prática dos crimes a ele imputados, sob pena de afronta ao princípio da presunção de inocência. Assim, não pode a prisão preventiva conter qualquer juízo antecipado de culpabilidade em sua fundamentação, ante a expressa imposição constitucional. ${ }^{75}$

75 SOUZA, Renato Perrotta de. "A inconstitucionalidade da prisão preventiva decretada como garantia da ordem pública”. Disponível na internet: http://www.emerj.tjrj.jus.br/paginas/trabalhos_conclusao/1semestre2013/trabalhos_12013/RenatoP errottaSouza.pdf. Rio de Janeiro, 2013, p.15. 
Desse modo, conclui-se que a prisão preventiva apresenta mera natureza cautelar, pois que nela não se cogita da análise do mérito da demanda. Do contrário, a decretação da medida caracterizaria um juízo sumário de culpa e a antecipação da pena, o que encontra expressa vedação na Constituição Federal.

Quanto à sua instrumentalidade, não há qualquer tipo de divergência na doutrina e jurisprudência pátrias. A título ilustrativo, vejamos as definições fornecidas por Afrânio Silva Jardim e Fernando Capez, respectivamente:

(...) a prisão provisória em nosso direito tem natureza acauteladora, destinada a assegurar a eficácia da decisão a ser prolatada ao final, bem como a possibilitar a regular instrução probatória. Trata-se de tutelar os meios e os fins do processo de conhecimento e, por isso mesmo, de tutela da tutela." 76

(...) trata-se de prisão de natureza puramente processual, imposta com finalidade cautelar, destinada a assegurar o bom desempenho da investigação criminal, do processo penal ou da execução da pena." 77

Inequívoco portanto, o entendimento de que a prisão preventiva não tem por finalidade a tutela do direito material violado, mas sim a proteção do processo de conhecimento. Afirma-se, assim, a sua cautelaridade: não é a prisão um fim em si, mas um instrumento de proteção da efetividade do próprio processo ao qual ela está vinculada.

\section{2 - PRESSUPOSTOS E FUNDAMENTOS PARA DECRETAÇÃO DA PRISÃO PREVENTIVA}

O tema das prisões preventivas encontra-se disposto no Código de Processo Penal no Capítulo III, "Da Prisão Preventiva”. No art. 312 estão dispostos os requisitos e fundamentos a dar ensejo à medida:

\footnotetext{
${ }^{76}$ JARDIM, Afrânio Silva. Direito Processual Penal. $11^{\mathrm{a}}$ ed. Rio de Janeiro: Forense, 2002, p.45.

${ }^{77}$ CAPEZ, Fernando. Curso de Processo Penal. 12a ed. São Paulo: Saraiva, 2005, p.228.
} 
Art. 312 - "a prisão preventiva poderá ser decretada como garantia da ordem pública, da ordem econômica, por conveniência da instrução criminal, ou para assegurar a aplicação da lei penal, quando houver prova da existência do crime e indício suficiente de autoria." (grifou-se e destacou-se)

Como medida cautelar que é, a prisão preventiva obedece aos requisitos comuns a toda e qualquer cautela, quais sejam, o fumus boni iuris e o periculum in mora. Tratam-se, respectivamente, da plausabilidade do direito e do perigo da demora na prestação jurisdicional. No processo penal, contudo, devido à peculiaridade dos interesses envolvidos (pretensão punitiva do Estado x liberdade de locomoção do acusado), esses dois pressupostos se transmudam para o que se convencionou denominar fumus comissi delicti e periculum libertatis.

Como não há direito subjetivo a ser tutelado em âmbito penal, o fumus comissi delicti traduz a probabilidade da condenação, a materialidade do delito e a existência de indícios capazes de apontar sumariamente a autoria do acusado. Deve, portanto, haver razoável material comprobatório da materialidade do delito. ${ }^{78}$

O periculum libertatis, por sua vez, consiste no risco que a liberdade do acusado representa para o inquérito policial ou para a regular tramitação do processo. Trata-se de situação de perigo concreta, criada, exclusivamente, pela conduta do sujeito passivo do processo. ${ }^{79}$

Esse perigo relaciona-se com os fundamentos previstos no art. 312 do CPP, quais sejam: a garantia da ordem pública, da ordem econômica, a conveniência da instrução criminal ou a garantia de aplicação da lei penal. Trata-se dos pilares a justificar o decreto provisório.

\footnotetext{
${ }^{78}$ LOPES JÚNIOR, Aury. Prisões Cautelares. $4^{\mathrm{a}}$ Ed. São Paulo: Saraiva, 2013, p. 26.

79 SOUZA, Renato Perrotta de. "A inconstitucionalidade da prisão preventiva decretada como garantia da ordem pública”. Disponível na internet: http://www.emerj.tjrj.jus.br/paginas/trabalhos_conclusao/1semestre2013/trabalhos_12013/RenatoP errottaSouza.pdf. Rio de Janeiro, 2013, p.10.
} 
Diga-se uma vez mais que o risco representado pela liberdade do acusado necessita ser concretamente justificado, é preciso que se configure uma ameaça factível, capaz de ser plenamente demonstrada:

\begin{abstract}
"Cabe ao juiz, em cada caso, analisar os fatos e perquirir se existem provas capazes de afirmar pelo menos um dos fundamentos, não bastando a mera presunção, devendo a decisão ser fundamentada, haja vista que se a Constituição proclama a 'presunção de inocência do réu ainda não definitivamente condenado', como pode o juiz presumir que ele vai fugir, que vai prejudicar a instrução, que vai cometer novas infrações? (...) É preciso que haja nos autos prova que leve o magistrado a tais informações." ${ }^{\circ 0}$
\end{abstract}

Portanto, deve ser apresentado no processo um fato claro, um temor sério que em nada tem a ver com o mérito da demanda em si, mas sim com a própria funcionalidade da Justiça, compreendendo-se no termo as investigações policiais durante o inquérito e a instrução probatória durante o processo. Vejamos, então, cada um desses fundamentos.

"Assegurar a aplicação da lei penal" significa resguardar eventual execução da pena, quando findo o processo. Ao final da tramitação processual, em caso de condenação, fica o condenado submetido à execução de uma pena que, em regra, será privativa de liberdade, nos termos da legislação. Portanto, em última análise, é a prisão para evitar que o imputado se evada, esvaziando o conteúdo da sentença penal condenatória por impedir a aplicação da pena cominada. $\mathrm{O}$ risco de fuga não pode ser presumido, tem que estar fundado em circunstâncias concretas. ${ }^{81}$

"Conveniência da instrução criminal" diz respeito aos atos probatórios produzidos em juízo. A instrução nada mais é do que o momento processual destinado a produzir meios de prova, necessários para a obtenção do veredicto final. Portanto, este fundamento autoriza o decreto prisional nos casos em que houver sinais claros de que o réu fará desaparecer provas do crime, apagará vestígios, subornará ou ameaçará

\footnotetext{
${ }^{80}$ TOURINHO FILHO, Fernando da Costa. Código de Processo Penal Comentado. $6^{\mathrm{a}}$ ed. Vol. 1. São Paulo: Saraiva, 2001. p.576.

${ }^{81}$ LOPES JÚNIOR, Aury. Prisões Cautelares. $4^{\text {a }}$ Ed. São Paulo: Saraiva, 2013, p. 95.
} 
testemunhas, etc. Busca-se, portanto, assegurar a prova processual contra a ação do réu, desde que haja evidência concreta de que ele irá agir.

Note-se que estes dois fundamentos são puramente processuais, associam-se ao caráter instrumental da prisão preventiva, eis que visam resguardar a efetividade da atividade jurisdicional, sem que importe a medida em antecipação de pena ou presunção antecipada de culpa por parte do magistrado. A prisão é decretada por motivos processuais, que em nada se aproximam do mérito da demanda.

A “ordem econômica", por sua vez, caracteriza-se pela amplitude e vagueza do termo, mostrando-se bastante controvertida a delimitação do conceito. Este fundamento fora introduzido no Código de Processo Penal através da Lei ${ }^{\circ}$ 8.884/94 (Lei Antitruste). Diz-se que esta disposição tem por fim a proteção do erário face a possibilidade de ocorrência de crimes econômicos, para evitar a criação de um contexto de instabilidade de mercado.

No entanto, não há qualquer tipo de consenso acerca dos seus limites interpretativos, o que gera uma situação de insegurança jurídica reprovável em se tratando de matéria penal. De todo modo, como na prática são poucas as decisões que fundamentam a prisão preventiva sob a justificativa de que se deve resguardar a ordem econômica, o tema não enseja grandes discussões doutrinárias.

$\mathrm{Na}$ realidade dos tribunais, o grande fundamento a suscitar a medida é a garantia da ordem pública, conceito também indeterminado e que, por ser extremamente genérico, confere aos magistrados um grau de discricionariedade muito grande. Na prática, o termo acabou se tornando verdadeiro standard, cláusula aberta utilizada por juízes e tribunais para 
justificar prisões sumárias por imperativos de segurança pública ${ }^{82}$, que em nada tem a ver com o processo penal em que decretadas.

Incumbe, portanto, analisar detidamente o conceito de ordem pública e a forma como ele é interpretado pela doutrina e jurisprudência para, ao final, demonstrar como essa terminologia flexibiliza a garantia constitucional da presunção da inocência (art. $5^{\circ}$, LVII), sobretudo quando diante de "potenciais inimigos", indivíduos cuja periculosidade é incontestável. Aqui, sem dúvidas, incide o fenômeno do direito penal do inimigo.

\section{3 - A ORDEM PÚBLICA COMO JUSTIFICATIVA PARA DECRETAÇÃO DE PRISÕES PREVENTIVAS}

Dada a amplitude do termo e a ausência de um conteúdo seguro que dele se possa extrair de plano, foram propostos distintos conceitos pela doutrina e pelos tribunais. A jurisprudência, apesar de muitas vezes utilizar o termo sem nem mesmo explicitar os seus limites, foi quem se encarregou de delinear os seus contornos de forma mais clara.

Um dos sentidos atribuídos pelos tribunais ao termo fora o de que consiste a ordem pública na sensação de paz e tranqüilidade social. Nesse sentido, quando o delito praticado causa grande clamor social, gerando indignação popular e uma repercussão social demasiado negativa, estaria autorizado o decreto prisional, pois o fato criou uma situação de instabilidade dentro da sociedade.

\footnotetext{
${ }^{82}$ SOUZA, Renato Perrotta de. "A inconstitucionalidade da prisão preventiva decretada como garantia $d a$ ordem pública". Disponível na internet: http://www.emerj.tiri.jus.br/paginas/trabalhos_conclusao/1semestre2013/trabalhos 12013/RenatoP errottaSouza.pdf. Rio de Janeiro, 2013.
} 
No entanto, este conceito de ordem pública é genérico demais. Como se sabe, o crime, por si só, gera abalo social, tendo em vista que o delito nada mais é do que um comportamento reprovável pela sociedade. Se este sentido de ordem pública fosse utilizado para a decretação da prisão preventiva, qualquer crime a ensejaria, tornando a prisão preventiva compulsória, e não medida de excepcionalidade.

Além disso, ao assim agir, estaria o magistrado respondendo a um anseio coletivo, que nada tem de jurídico, justificando a prisão provisória não em razão do risco que o agente representa para o processo, mas em atenção ao sentimento de revolta gerado pelo crime na coletividade. Perdese, com isso, a instrumentalidade da medida, violando-se ainda o princípio da presunção da inocência, presumindo-se culpado o réu antes do trânsito em julgado da sentença penal condenatória.

Atento a ausência de razoabilidade dessa justificativa para decretação das prisões preventivas, o Supremo Tribunal Federal já decidiu de maneira reiterada que o estado de comoção social e de eventual indignação popular não pode justificar, por si só, a decretação da prisão cautelar, dado o grau de abstração dos conceitos, sob pena de violação ao direito fundamental à liberdade. ${ }^{83}$

De todo modo, não obstante tenha a jurisprudência da Corte ao longo do tempo construído esse entendimento, em âmbito regional ainda podem ser encontradas decisões judiciais que decretam a prisão preventiva dos acusados com base nesses argumentos.

Outros fatores suscitados para justificar a decretação de prisões preventivas para garantia da ordem pública são a gravidade do delito praticado e a necessidade de resguardar a credibilidade da justiça. Quanto a esses argumentos, que não raro fundamentam o decreto prisional nos

\footnotetext{
${ }^{83}$ STF, HC n ${ }^{\text {o }}$ 97.466/RS, $2^{\text {a }}$ Turma, Rel. Min. Celso de Mello, j. 25/08/2009, DJ 06/11/2009; STF, HC n ${ }^{\circ}$ 71.289/RS, $1^{\text {a }}$ Turma, Rel. Min. Ilmar Galvão, j. 09/08/1994, DJ 06/09/1996
} 
tribunais estaduais, a jurisprudência do Supremo também se posiciona pelo seu descabimento.

Com efeito, em relação à gravidade do delito praticado, em distintos precedentes da Corte, afirma-se o entendimento de que, mesmo que se trate de pessoa acusada da suposta prática de crime hediondo, não se revela possível a decretação da prisão preventiva até que sobrevenha sentença penal condenatória irrecorrível, pois que, do contrário, a medida importaria em presunção antecipada de culpa, violando-se o princípio da presunção de inocência contido no art. $5^{\circ}$, LVII da CF/88. ${ }^{84}$

Portanto, a gravidade abstrata do delito não justifica a medida, eis que retira dela o seu caráter de proteção ao processo, traduzindo, na prática, a intenção de antecipar a pena, de manter o indivíduo preso presumindo-se que cometera o crime.

A credibilidade da justiça, por sua vez, traduz uma tentativa de remediar o desgaste do Poder Judiciário, de melhorar a imagem da justiça frente à população. O descrédito que a sociedade atribui ao Judiciário advém de um sentimento comum de insegurança, da visão de que a criminalidade constitui um dos principais problemas sociais da atualidade. Boa parte da população vê a justiça como parte desta problemática, dada a sua lentidão e a pretensa sensação de impunidade que norteia o senso comum, ainda que o Brasil apresente uma das maiores populações carcerárias de todo o mundo.

Evidentemente, essa justificativa é totalmente alheia ao processo penal, não há qualquer razão de ordem processual que justifique a adoção da medida, servindo a prisão tão-somente para satisfazer anseios sociais, para dar uma resposta à sociedade. Essa visão de ordem pública, sem dúvidas, viola a garantia da presunção de inocência, considerando-se culpado o acusado antes de sua condenação definitiva. Viola-se 
flagrantemente o direito à liberdade do acusado em prol da criação de um sentimento de satisfação para com o Judiciário, afastando-se em muito da instrumentalidade que caracteriza a prisão preventiva.

O STF também já posicionou diversas vezes sobre o tema, afirmando não se revestir de idoneidade jurídica, para justificar a prisão preventiva, a alegação de que o réu deve ser mantido preso em nome da credibilidade das instituições. A ordem pública, portanto, constitui fundamento igualmente inidôneo quando vinculado à credibilidade da justiça. ${ }^{85}$

\section{4 - ORDEM PÚBLICA E A PERICULOSIDADE DO AGENTE}

\subsection{1 - Jurisprudência do STF e críticas doutrinárias}

$\mathrm{Na}$ prática, a despeito de outros significados extraídos da interpretação da expressão ordem pública (clamor social, credibilidade da justiça, gravidade do delito), o fator que prepondera nas decisões judiciais e que chancela a maioria dos decretos prisionais preventivos é a periculosidade do réu, terminologia que se associa diretamente à ideia de combate ao inimigo.

Por essa perspectiva, a prisão preventiva resta justificada em função do caráter perigoso do acusado, comprovado por sua reiterada atividade delitiva, devendo o mesmo ser neutralizado para que não venha a praticar novos delitos. Muitas vezes, a periculosidade do agente é aferida não apenas por seus comportamentos pretéritos, mas levando-se igualmente em consideração a forma pela qual o crime fora praticado.

Note-se, contudo, que este entendimento baseia-se em uma dupla presunção: presume-se que o acusado cometera o crime (algo que somente

\footnotetext{
${ }^{85}$ STF, HC n ${ }^{\circ}$ 80.719/SP, $2^{\text {a }}$ Turma, Rel. Min. Celso de Mello, j. 26/06/2001, DJ 28/09/2001; STF, $\mathrm{HC} \mathrm{n}^{\circ}$ 86.175/SP, $2^{\mathrm{a}}$ Turma, Rel. Min. Eros Grau, j. 19/09/2006, DJ 10/11/2006
} 
poderá ser provado ao final do processo), bem como que, se permanecer em liberdade, voltará a praticar outros delitos. ${ }^{86}$

Portanto, essa justificativa de que a liberdade do réu representa um risco para a sociedade, dada a possibilidade de reiteração delitiva, é pautada por suposições, por aspectos que estão associados à personalidade do réu e não à sua conduta propriamente (contra a qual sequer fora produzido um juízo de certeza capaz de condenar o acusado).

Como já previamente assinalado, o decreto prisional preventivo exige justificativas concretas, fatos determinados capazes de apontar a ameaça que o acusado representa para o processo. Ao se supor que o acusado, quando em liberdade, praticará novos crimes, está-se não apenas a desrespeitar essa exigência de concretude, como também a violar a garantia da presunção de inocência, qualificando o réu como criminoso mesmo antes de produzida uma sentença penal condenatória definitiva.

Inobstante as críticas constantemente trazidas a esse entendimento, fato é que a jurisprudência do Supremo Tribunal Federal permite o decreto prisional provisório calcado na periculosidade do agente, no risco de reincidência que ele representa. Para ilustrar esse posicionamento, leia-se a ementa do Agravo Regimental em Habeas Corpus $n^{\circ}$ 127.403/TO, absolutamente recente e que resume bem a posição da Corte quanto ao sentido atribuível à ordem pública:

EMENTA Agravo regimental em habeas corpus. Processual Penal. Preventiva (CPP, art. 312). Alegada falta de fundamentação para justificar a medida extrema. Não ocorrência. Gravidade em concreto da conduta e a real periculosidade dos agravantes que legitimaram, entre outros aspectos, a custódia preventiva com fundamento na garantia da ordem pública. Precedentes. Inexistência de inovação dos fundamentos justificadores da medida extrema. Regimental não provido. 1 . As circunstâncias da prática criminosa narradas no título prisional, que demonstraram sua gravidade em concreto e a real periculosidade dos agravantes, legitimaram, entre outros aspectos, a custódia preventiva com

\footnotetext{
${ }^{86}$ ALMEIDA, Gabriel Bertin de. Afinal, quando é possível a decretação de prisão preventiva para a garantia da ordem pública?. In Revista Brasileira de Ciências Criminais. São Paulo, $\mathrm{n}^{\circ}$ 44, p. 71-85, jul-set/2003.
} 
fundamento na garantia da ordem pública, não havendo que se falar em inovação dos fundamentos justificadores da medida extrema. 2. Consoante a consolidada jurisprudência da Corte, "quando da maneira de execução do delito sobressair a extrema periculosidade do agente, o decreto de prisão ganha a possibilidade de estabelecer um vínculo funcional entre o modus operandi do suposto crime e a garantia da ordem pública. Isso na linha de que a liberdade do paciente implicará a inseguranca objetiva de outras pessoas, com sérios reflexos no seio da própria comunidade" $\left(\mathrm{HC} \mathrm{n}^{\circ}\right.$ 111.244/SP, Segunda Turma, Relator o Ministro Ayres Britto, DJe de 26/6/12). 3. Agravo regimental ao qual se nega provimento. ${ }^{87}$ (grifou-se e destacou-se)

Desse modo, legitima-se a decretação de prisões preventivas com base no perigo que o agente representa para a sociedade se mantido em liberdade, na possibilidade dele voltar a delinquir. Trata-se, evidentemente, de um juízo subjetivo e arbitrário, eis que relacionado às características apresentadas pelo acusado. Presume-se que ele praticara o crime do qual é acusado e que voltará a praticar crimes se estiver solto. Não há como negar que essa prisão é decorrente de um juízo de culpabilidade antecipado, em contraposição ao que garante a Constituição Federal em seu art. $5^{\circ}$, LVII.

É justamente por isso que diversos autores defendem a inconstitucionalidade dessa interpretação, seja por conta da violação ao princípio da presunção da inocência, seja porque ela se afasta em muito do caráter processual e instrumental da prisão preventiva, como medida cautelar que é. ${ }^{88}$

Fato é que, na experiência prática, a grande maioria dos tribunais decreta a prisão preventiva do acusado fundamentando com base na garantia da ordem pública, em função do risco que a liberdade do agente representa para a sociedade, devido à sua periculosidade, comprovada pelo modus operandi da ação criminosa, bem como pelos antecedentes criminais que apresenta.

\footnotetext{
${ }^{87}$ STF, AgRg no HC n ${ }^{\circ}$ 127.403/TO, $2^{\text {a }}$ Turma, Rel. Min. DIAS TOFFOLI, j. 25/05/2015, DJ $30 / 06 / 2015$

88 “(...) as prisões preventivas para garantia da ordem pública ou da ordem econômica não são cautelares, portanto, são substancialmente inconstitucionais" LOPES JUNIOR, Aury, Prisões Cautelares, $4^{\mathrm{a}}$ Ed. São Paulo: Saraiva, 2013, p. 108
} 


\title{
3.4.2 - Prisão preventiva como política de segurança pública: necessidade de contenção dos perigosos
}

Na prática, diante da distorção no uso da prisão cautelar, revela-se claro que o instituto se convertera em um verdadeiro método de defesa contra indivíduos ameaçadores. A prisão preventiva escorada na garantia da ordem pública acaba sendo utilizada com uma função de "prevenção especial, na medida em que o legislador pretende contribuir à segurança da sociedade" 89 :

"A prisão preventiva, que deveria proteger a eficácia do processo, passa a ser utilizada como meio de resguardo da segurança pública e da paz social, contra indivíduos supostamente perigosos, tudo sobre a alcunha da "garantia da ordem pública", equivalendo-se, portanto, a um verdadeiro juízo antecipado de culpabilidade." ${ }^{90}$

No mesmo sentido, importante destacar as considerações feitas pelo

Desembargador do Tribunal de Justiça do Rio de Janeiro Paulo Rangel:

\begin{abstract}
“(...) não podemos confundir prisão cautelar com política séria de combate à violência, ou seja, nada tem a ver com a prisão cautelar os altos índices de violência urbana que assolam nosso país. Se há roubo, homicídios, estupros, etc, ocorrendo nas grandes metrópoles, deve o Estado adotar medidas necessárias para conter essa onda de violência e não culparmos o Judiciário que não lançou mão de uma medida cautelar para contê-la. Uma coisa é a certeza de que nas ruas não há policia, outra, bem diferente, é, em decorrência disso, haver necessidade de, no curso do processo, o réu ser preso". ${ }^{91}$
\end{abstract}

Portanto, o instituto passa a ser constantemente utilizado como estratégia de neutralização de indivíduos potencialmente perigosos, reforçado pelo papel desempenhado pela mídia, capaz de rotular determinados indivíduos acusados da prática de um crime como verdadeiros

\footnotetext{
${ }^{89}$ SANGUINÉ, Odone. A inconstitucionalidade do clamor público como fundamento da prisão preventiva. In Revista de Estudos Criminais. Porto Alegre, nº10, 2003, p.115.

${ }^{90}$ SOUZA, Renato Perrotta de. "A inconstitucionalidade da prisão preventiva decretada como garantia da ordem pública”. Disponível na internet: http://www.emerj.tjrj.jus.br/paginas/trabalhos_conclusao/1semestre2013/trabalhos 12013/RenatoP errottaSouza.pdf. Rio de Janeiro, 2013, p.17.

${ }^{91}$ RANGEL, Paulo. Direito Processual Penal, $16^{\mathrm{a}}$ ed. Rio de Janeiro: Lumen Juris, 2009, p. 712.
} 
criminosos, gerando na sociedade uma sensação de instabilidade, bem como demandas por um Judiciário mais repressivo, tudo isso sob a ilusão de que o aprisionamento (sobretudo dos que se adequam ao estereótipo criminal) é capaz de resolver o problema da violência nas ruas.

Sobre o papel dos veículos jornalísticos na qualificação do perigo representado pelo acusado, fundamental a crítica de Aury Lopes Júnior:

\begin{abstract}
"Há que se atentar para uma interessante manobra feita rotineiramente: explorase, midiaticamente, determinado fato (uma das muitas "operações" com nomes sedutores, o que não deixa de ser uma interessante manobra de marketing policial), muitas vezes com proposital vazamento de informações, gravações telefônicas e outras provas colhidas, para colocar o fato na pauta pública de discussão (a conhecida teoria do agendamento) (...) Ou seja, constrói-se midiaticamente o pressuposto da posterior prisão cautelar. Na verdade, a situação fática nunca existiu; trata-se de argumento forjado" ${ }^{92}$
\end{abstract}

Como se vê, o trabalho dos meios de comunicação contribui para que se desenvolva um processo de demonização do acusado, a partir da divulgação de suas imagens, ficha de antecedentes criminais, bem como de questões internas do inquérito ou do processo penal referente ao fato em análise. Com isso, fortalece-se a ideia de que se trata o agente de verdadeiro criminoso, extremamente perigoso e que, caso permaneça em liberdade, voltará a delinquir. Justifica-se, pois, o decreto prisional fundado na periculosidade do sujeito, por razões de segurança.

Nesse cenário, evidente que a visão estereotipada do criminoso construída pela sociedade tem papel de destaque nas manchetes dos jornais que, por sua vez, influencia o trabalho dos magistrados: tratando-se o acusado de alguém pobre, de cor escura e, eventualmente, com antecedentes criminais, nele estão presentes os atributos de um verdadeiro meliante que, por isso, deve ser neutralizado. Sobretudo se estamos diante de um crime contra a vida, um crime contra o patrimônio ou um crime de tráfico de

\footnotetext{
${ }^{92}$ LOPES JUNIOR, Aury, Prisões Cautelares, $4^{\text {a }}$ Ed. São Paulo: Saraiva, 2013, p. 110.
} 
drogas (delitos frequentemente associados às camadas pobres e marginalizadas).

Neste ponto, basta elaborar simples pesquisa de jurisprudência nos sítios eletrônicos dos tribunais estaduais para constatar que, na esmagadora maioria dos casos em que se discute a manutenção de prisões preventivas em razão da periculosidade do agente, este é acusado da prática dos crimes de tráfico ilícito de entorpecentes, roubo ou homicídio.

Vejamos, à título ilustrativo, trecho da ementa de acórdão extremamente recente proferido pela $3^{\mathrm{a}}$ Câmara Criminal do Tribunal de Justiça do Rio de Janeiro, em que se discute o decreto prisional provisório calcado no perigo representado pelo agente, acusado da prática do crime de roubo:

HABEAS CORPUS. Artigo 157, c/c art. 14, II do CP. Excesso de prazo. É cediço que o prazo para o término da instrução não pode resultar de mera soma aritmética de todos os atos processuais, devendo se exigir do Juiz, apenas, que zele pela regularidade do processo, adotando as providências necessárias para que o julgamento se realize dentro de um prazo razoável. Segundo as informações prestadas, o processo tem se estendido, pois o Ministério Público insistiu pela oitiva da vítima, como de direito. De acordo com o site do Tribunal, o último andamento do processo se refere à expedição de nova carta precatória, com urgência. Desta maneira, não se vislumbra a inércia do Judiciário, de plano, a única hipótese que poderia ensejar excesso de prazo na instrução criminal.. Ademais, o crime imputado ao paciente foi praticado com violência, aspectos que indiciam a periculosidade do acusado que, solto, acarreta evidente ameaca à ordem pública. Portanto, necessária a manutencão da prisão preventiva para garantia da ordem pública e da instrução criminal, além do intuito de impedir a reiteracão de atos criminosos. Por último, primariedade, residência fixa e/ou atividade laboral lícita não são capazes, por si só, de afastar a aplicação dos requisitos autorizadores do art. 312 do CPP enquanto justificativas para sua custódia cautelar. Denegação da ordem. (grifou-se e destacou-se) ${ }^{93}$

Como se vê, a fundamentação que embase a restrição à liberdade do acusado é mínima: justifica-se a manutenção da prisão preventiva com base no modus operandi da atividade criminosa, o qual por si só já indica a periculosidade do réu e o risco de que venha a reincidir. Note-se como a

\footnotetext{
${ }^{93}$ TJRJ, HC n ${ }^{\circ}$ 0049156-30.2015.8.19.0000, $3^{\text {a }}$ Câmara Criminal, Rel. Min. Mônica Tolledo de Oliveira, j. 20/10/2015
} 
argumentação se compatibiliza com a jurisprudência do Supremo Tribunal Federal previamente destacada. Em comum, o fato de se utilizar da medida (cautelar) a partir de meras suposições, da presunção de que o réu, em liberdade, voltará a delinquir.

Quanto ao tema, não há como dissociá-lo do denominado direito penal do autor: a atividade da justiça criminal, nesse ponto, não foca suas atenções para o resguardo do processo penal, mas sim sobre a personalidade do réu, supostamente voltada para o crime. Nesse ponto, a figura típica de um membro das classes subalternas aliadas a algumas anotações criminais terão influência decisiva na decisão do magistrado.

Segundo Augusto Thompson, eis o raciocínio para que se neutralize um "típico criminoso":

"pode ser que dessa vez não tenha feito nada, mas trata-se, evidentemente, de um criminoso, justificando-se, pois, aproveitar a oportunidade para puni-lo pelo que deve ter feito ou pelo que fará, se for deixado livre". ${ }^{4}$

Levando-se em consideração a suposta periculosidade do agente, muitas arbitrariedades são cometidas, determinando-se o encarceramento de indivíduos com base em presunções, em propriedades dos acusados hábeis a qualificá-los como criminosos desde o primeiro momento.

Traçando-se um paralelo com as formulações de Jakobs, pode-se caracterizar a prisão preventiva como verdadeiro adiantamento da punibilidade. Na concepção do autor, o instituto é qualificado como coação física que se dirige ao indivíduo que, ainda que não oculte provas ou fuja, põe em perigo a tramitação ordenada do processo com os seus "instintos" e "medos". Portanto, opera-se uma restrição prévia em sua liberdade em

\footnotetext{
${ }^{94}$ THOMPSON, Augusto. Op. Cit, p. 68.
} 
razão da ameaça que representa, reflexo direto do fenômeno do direito penal do inimigo. ${ }^{95}$

Assim, por meio desse instituto previsto na legislação, legitima-se tratamento distinguido a determinada classe de autores com a marca da periculosidade, relativizando garantias constitucionais fundamentais como a liberdade de locomoção (art. $5^{\circ}, \mathrm{XV}$ ) a presunção da inocência (art. $5^{\circ}$, LVII) e o devido processo legal (art. 5\%, LIV), encarcerando-os sumariamente, justificando-se a medida através de imperativos de segurança pública. Para eles, portanto, a lei deve ser aplicada distintamente, com maior rigor.

\subsection{3 - Direito penal de periculosidade presumida: quando a exceção vira a regra}

Em razão do desvirtuamento do instituto, uma medida que deveria ser utilizada apenas em hipóteses excepcionais acaba por se tornar a regra. A prisão preventiva como garantia da ordem pública, em determinadas situações, passa a ser quase automática.

Segundo Eugenio Raul Zaffaroni, todo o fenômeno do direito penal do inimigo se manifesta na América Latina da atualidade mediante medidas de contenção para suspeitos perigosos. Institucionaliza-se a partir de um "direito penal de periculosidade presumida", que funciona como base para a imposição de penas sem sentença penal condenatória definitiva para a maioria dos presos:

"A característica mais destacada do poder punitivo latino-americano atual em relação ao aprisionamento é que a grande maioria - aproximadamente $3 / 4$ - dos presos está submetida a medidas de contenção, porque são processados não condenados (...) tudo se converteu em privação de liberdade sem sentença firme, apenas por presunção de periculosidade (...) a medida cautelar é pena cautelar, ou

\footnotetext{
${ }^{95}$ JAKOBS, Günther. MELIÁ, Manuel Cancio. Op. Cit, p.38.
} 
seja, por precaução, o poder punitivo é exercido condenando-se materialmente todos os acusados a uma medida e revisando-se com grande parcimônia essas condenações, num processo que se arrasta anos a fio, com o intuito de verificar se corresponde a uma pena formal. $\mathrm{O}$ desencarceramento ou a cessação da prisão preventiva ou provisional representa uma absolvição, pois corresponde a quase todos os seus efeitos. ${ }^{96}$

No Brasil, essa tendência é confirmada pelas estatísticas: segundo relatório sobre o uso da prisão preventiva nas Américas elaborado pela Comissão Interamericana de Direitos Humanos (CIDH) da Organização dos Estados Americanos (OEA), produzido em dezembro de 2013, cerca de $40 \%$ da população carcerária no país é formada por presos provisórios, presos sem julgamento. $\mathrm{O}$ documento afirma ainda que o Brasil tem a segunda maior população carcerária do continente, atrás apenas dos Estados Unidos. Os números são alarmantes: 550 mil presos no total, dos quais 217 mil aguardam julgamento. ${ }^{97}$

Diante desses dados, não há como não concluir que a prisão preventiva consiste em um grande mecanismo de encarceramento e neutralização de indivíduos potencialmente perigosos, passando a ser regra e não mais uma medida excepcional. Dado o perfil da esmagadora maioria dos presos (pobres, negros e jovens), é perceptível como o instituto se transformou em verdadeira expressão do fenômeno do direito penal do inimigo, justificando o confinamento de sujeitos com base em sua periculosidade presumida, tendo a jurisprudência do Supremo confirmado a constitucionalidade dessa atuação.

\footnotetext{
${ }^{96}$ ZAFFARONI, E. Raul. Op. Cit, p.70.

97 Disponível em: http://www.oas.org/es/cidh/ppl/informes/pdfs/Informe-PP-2013-es.pdf, p. 1718. Acesso em 18 out de 2015.
} 


\section{CAPÍTULO 4 - A ALOCAÇÃo DE PRESOS NO REGIME DISCIPLINAR DIFERENCIADO}

O regime disciplinar diferenciado, introduzido no Brasil no início do século XXI e em conformidade com uma tendência punitivista muito clara, constitui sem dúvidas uma das expressões mais óbvias do fenômeno do direito penal do inimigo na legislação brasileira.

Trata-se de uma estratégia clara do Estado em conferir tratamento diferenciado no âmbito penitenciário aos presos de "maior periculosidade", legitimando-se, em razão do suposto risco que representam para o estabelecimento prisional e para a própria sociedade, restrições ainda maiores à liberdade desses detentos.

A medida, conforme se verá, enfrenta enorme questionamento por parte da doutrina penal, tendo em vista a flexibilização de garantias constitucionais fundamentais, exigindo-se o cumprimento da pena em situação desumana, de isolamento quase permanente.

Ademais, ao impor ao preso potencialmente perigoso tais condições, evidencia-se que esta iniciativa tem por fim neutralizá-lo, mantê-lo alheio a qualquer tipo de contato humano.

Para melhor explicar o regime disciplinar diferenciado e suas características, faz-se necessário, em primeiro lugar, identificar suas raízes, o contexto social que dera ensejo ao seu desenvolvimento no âmbito das penitenciárias, ganhando aos poucos contornos mais claros, até levar a edição da Lei ${ }^{\circ}$ 10.792/03. 


\section{1 - A GÊNESE DO RDD: REBELIÕES NOS PRESÍDIOS}

A ideia de alocar determinados presos em um regime de cumprimento de pena mais rigoroso e restritivo surgiu como reação às distintas rebeliões ocorridas em presídios estaduais no início dos anos 2000, sobretudo nos estados de São Paulo e Rio de Janeiro.

No estado de São Paulo, no ano de 2001, ocorrera uma das maiores rebeliões de presos já registrada. O conflito envolveu vinte e cinco unidades prisionais da Secretaria de Administração Penitenciária e quatro cadeias sob responsabilidade da Secretaria de Segurança Pública do Estado. O objetivo era fazer pressão sobre as autoridades governamentais, que haviam decidido pela transferência de membros do PCC (Primeiro Comando da Capital), principal facção criminosa de São Paulo, para presídios distantes da capital. $^{98}$

O levante, comandado por líderes de facções criminosas operando de dentro dos presídios, contou com ampla cobertura midiática, mobilizando mais de 27 mil presos, desencadeando a morte de 16 detentos e deixando diversos feridos. O episódio impressionou pela facilidade de acesso que os presos tinham a armas, granadas e telefones celulares. ${ }^{99}$

Diante desse contexto de instabilidade, foram tomadas soluções de urgência: a Secretaria de Administração do Estado de São Paulo passa a editar resoluções restringindo direitos dos detentos. Uma delas, a resolução $\mathrm{n}^{\circ} 26\left(\mathrm{SAP} / \mathrm{SP}^{\circ}\right.$ 26), estabeleceu o regime disciplinar diferenciado, o qual, em um primeiro momento, restringiu-se a cinco unidades prisionais do estado: Casa de Custódia de Taubaté, Penitenciárias I e II de Presidente Venceslau, Penitenciária de Iaras I e II e de Avaré.

\footnotetext{
98 CARVALHO, Salo de. FREIRE, Christiane Russomano "O regime disciplinar diferenciado: notas críticas à reforma do sistema punitivo brasileiro”. Disponível na internet: http://www.defensoria.sp.gov.br/dpesp/Repositorio/30/Documentos/273.pdf. In Revista Transdisciplinar de Ciências Penitenciárias, 4(1):7-26, Jan-Dez./2005

99 Disponível: http://acervo.oglobo.globo.com/em-destaque/maior-rebeliao-da-historia-do-paisexpos-mazelas-do-sistema-penitenciario-11167174. Acesso em 18 de out 2015.
} 
Aos poucos, a medida passa a ser aplicada em outros presídios: a resolução SAP/SP $\mathrm{n}^{\circ} 59$ institui o regime disciplinar diferenciado no Complexo Penitenciário de Campinas (Hortolândia).

No estado do Rio de Janeiro, a rebelião realizada no presídio de Bangu I em 2002, supostamente comandada por Fernandinho Beira-Mar, a qual levou a morte quatro traficantes de facções criminosas rivais, impulsionou a implementação imediata do Regime Disciplinar Especial de Segurança (RDES).

Com o tempo, a Secretaria de Administração Penitenciária do Rio de Janeiro reeditou a medida e generalizou-a para outras unidades penitenciárias. Nesse contexto, convém destacar a opinião do Secretário de Administração Penitenciária à época, Astério Pereira dos Santos, quanto aos objetivos da medida:

\begin{abstract}
"No que pertine ao Regime Disciplinar Especial de Segurança ora implantado, tanto aqui no Rio de Janeiro, quanto em São Paulo, está ele em consonância com o que se acabou de expor, deixando certo que esse trata de um imperativo de disciplina, mas muito mais que isto, de uma medida destinada a afastar líderes violentos e sanguinários, de exacerbada periculosidade, do convívio com os demais presos, que eles subjugam e usam como massa de manobra em suas rebeldias, obrigando-os a fazer rebeliões, motins e, até mesmo, greve de fome, como se pôde ver na semana passada." ${ }^{100}$ (grifou-se e destacou-se)

Como se vê, a medida se presta justamente a tratar de maneira distinta os "criminosos comuns" e os "criminosos de alta periculosidade", criando níveis de controle e disciplina maiores quanto aos últimos. Legitima-se, portanto, um atuar mais repressivo contra determinada classe
\end{abstract} de indivíduos presos.

As experiências ocorridas no Rio de Janeiro e em São Paulo, massificadas pela intensa cobertura midiática atribuída às rebeliões nos presídios, estimularam o Congresso. Nas palavras do professor Salo de

\footnotetext{
${ }^{100}$ DOS SANTOS, Astério Pereira. "Regime Disciplinar Especial - Legalidade e Legitimidade". Disponível em: http://www.seap.ri.gov.br, Acesso em 22 ago de 2014.
} 
Carvalho, havia também outros fatores determinantes para a legitimação de políticas mais restritivas e repressivas:

\begin{abstract}
"A medida de recrudescimento disciplinar esteve igualmente relacionada com a necessidade do Poder Público reafirmar o seu controle sobre os estabelecimentos prisionais (...) Naquele momento, a construção do anti-herói nacional personificado na figura do líder da facção Comando Vermelho, associada ao homicídio de dois Magistrados de Varas de Execuções Criminais - 14 de março de 2003 em São Paulo (SP) e 24 de março em Vitoria (ES) -, agregou o elemento que faltava para a implantação definitiva das medidas de maximização dos métodos de contenção e neutralização."101
\end{abstract}

Dentro desse contexto, em 2003, aproximadamente um ano após o episódio no Rio de Janeiro, entrou em vigor a lei $\mathrm{n}^{\circ} 10.792 / 2003$, a qual instituiu no âmbito da legislação federal o regime disciplinar diferenciado, promovendo alterações na Lei de Execuções Penais (Lei n ${ }^{\circ} 7.210 / 84$ ).

\title{
4.2 - REGIME DISCIPLINAR DIFERENCIADO: CONCEITUAÇÃO
}

Na Lei de Execuções Penais (Lei n ${ }^{\circ}$ 7.210/84), dentro da seção III, “Da Disciplina”, pode ser encontrada a subseção III, "Das Sanções e das Recompensas". Dentro desta subseção, no seu art. 53, inciso V, há a previsão do regime disciplinar diferenciado como sanção disciplinar.

Do teor do art. 53, portanto, constituiria o regime disciplinar diferenciado uma nova hipótese de sanção disciplinar, mais grave e marcada pelo isolamento do preso em relação aos demais.

No entanto, analisando-se as situações que dão ensejo a medida, revela-se evidente que o RDD não tem como natureza jurídica única a de constituir uma sanção disciplinar. Isso porque existem hipóteses aptas a legitimá-lo que não se caracterizam pela indisciplina do preso, mas sim por

101 CARVALHO, Salo de. FREIRE, Christiane Russomano "O regime disciplinar diferenciado: notas críticas à reforma do sistema punitivo brasileiro”. Disponível na internet: http://www.defensoria.sp.gov.br/dpesp/Repositorio/30/Documentos/273.pdf. In Revista Transdisciplinar de Ciências Penitenciárias, 4(1):17-18, Jan-Dez./2005 
razões de segurança interna (do estabelecimento prisional) e externa (da sociedade). Neste caso, a medida teria caráter acautelador.

Veja-se inclusive que, contrariamente ao que o termo regime disciplinar diferenciado indica, não se trata de um novo regime de cumprimento de pena, distinto dos regimes fechado, semiaberto ou aberto. Nesse sentido, oportuno destacar as definições de Julio Mirabete:

\footnotetext{
"Pela lei $\mathrm{n}^{\circ} 10.792$, de $1^{\circ}-12-2003$, foi instituído o regime disciplinar diferenciado, que não constitui um regime de cumprimento de pena em acréscimo aos regimes fechado, semiaberto e aberto, nem uma nova modalidade de prisão provisória, mas sim um regime de disciplina carcerária especial, caracterizado por maior grau de isolamento do preso e de restrições ao contato com o mundo exterior, a ser aplicado como sancão disciplinar ou como medida de caráter cautelar, tanto ao condenado como ao preso provisório, nas hipóteses previstas em lei." ${ }^{102}$ (grifou-se e destacou-se)
}

Quanto ao preso provisório, importante ressaltar que este também se encontra sujeito à aplicação da Lei de Execuções Penais (art. $2^{\circ}, \S$ único), de modo que, se presentes os pressupostos para a imposição da medida, poderá o juiz determinar que seja alocado no regime disciplinar diferenciado.

Conforme se verá posteriormente, a lei previu três hipóteses a fundamentar a alocação do preso no RDD, duas em caráter cautelar/preventivo e uma delas em caráter de sanção disciplinar. Por hora, vejamos as peculiaridades da medida.

\section{3 - CARACTERÍSTICAS DO REGIME DISCIPLINAR DIFERENCIADO}

O regime disciplinar diferenciado encontra-se previsto no art. 52 da Lei de Execuções Penais (Lei ${ }^{\circ}$ 7.210/84), localizando-se nos seus incisos as características da medida. Vejamos, pois, o disposto no referido dispositivo:

\footnotetext{
102 MIRABETE, Julio Fabbrini. FABBRINI, Renato N. Execução Penal, 12 ${ }^{\mathrm{a}}$ ed. São Paulo: Atlas, 2014, p. 150 .
} 
Art. 52 - (...) sujeita o preso provisório, ou condenado, sem prejuízo da sanção penal, ao regime disciplinar diferenciado, com as seguintes características:

I - duração máxima de trezentos e sessenta dias, sem prejuízo de repetição da sanção por nova falta grave de mesma espécie, até o limite de um sexto da pena aplicada;

II - recolhimento em cela individual;

III - visitas semanais de duas pessoas, sem contar as crianças, com duração de duas horas;

IV - o preso terá direito à saída da cela por 2 horas diárias para banho de sol.

Da redação dos incisos do art. 52, pode-se inferir que o regime disciplinar diferenciado sujeita o detento às seguintes condições: recolhimento em cela individual; visitas semanais de duas pessoas, sem contar crianças, por duas horas; saída diária, para banho de sol, igualmente por duas horas.

Trata-se de um regime marcado pelo afastamento do preso, que é privado do contato com os demais detentos, permanecendo isolado durante a maior parte do tempo. Como somente se faculta ao preso inserto no RDD duas horas de saída diária para banho de sol, infere-se que nas demais vinte e duas horas deve ele permanecer recluso, dentro da cela.

Nesse ponto, muitos questionam a constitucionalidade do instituto, sabendo-se que, nos termos da Constituição Federal de 1988, veda-se a aplicação de penas cruéis (art. $5^{\circ}$, XLVII da CF/88) e assegura-se aos presos “o respeito à integridade física e moral". ${ }^{103}$

Ademais, pelo nível quase total de isolamento imposto ao condenado e sabendo-se das parcas condições oferecidas pelos presídios brasileiros, muitos afirmam que o regime disciplinar diferenciado acarreta ao preso verdadeiro sofrimento físico e mental, assumindo uma feição maligna e rompendo com o fundamento constitucional de respeito à dignidade do ser humano (art. $1^{\circ}$, III da CF/88).

103 CARVALHO, Salo de. FREIRE, Christiane Russomano "O regime disciplinar diferenciado: notas críticas à reforma do sistema punitivo brasileiro”. Disponível na internet: http://www.defensoria.sp.gov.br/dpesp/Repositorio/30/Documentos/273.pdf. In Revista Transdisciplinar de Ciências Penitenciárias, 4(1):17-18, Jan-Dez./2005. 
De todo modo, não obstante as inúmeras críticas que surgiram no campo doutrinário em reação à edição da Lei $n^{\circ} 10.792 / 03$, os tribunais superiores já se pronunciaram sobre o tema para declarar a constitucionalidade da medida. Nos termos da jurisprudência, as garantias constitucionais não são ilimitadas, podendo ser restringidas por imperativos de ordem social e segurança pública, desde que observado o princípio da proporcionalidade. No caso do regime disciplinar diferenciado, teria o legislador atendido à essa exigência. ${ }^{104}$

Nesse sentido, dada a provisoriedade do regime e das restrições por ele impostas, não representaria violação aos princípios constitucionais em questão (princípio da dignidade humana, humanidade das penas e proibição da submissão do preso a tratamento desumano ou degradante (art. $1^{\circ}$, III, art. $5^{\circ}$, III e XLVII da CF/88). ${ }^{105}$

Apresentadas as características do regime, passemos agora ao tema que mais traz controvérsia e no qual a marca do direito penal do inimigo aparece com clareza: as hipóteses que fundamentam a alocação do preso no RDD.

\section{4 - HIPÓTESES QUE AUTORIZAM A APLICAÇÃO DO REGIME DISCIPLINAR DIFERENCIADO}

As situações que fundamentam a alocação do preso no regime disciplinar diferenciado encontram-se previstas no caput e parágrafos $1^{\circ} \mathrm{e}$ $2^{\circ}$ do art. 52 da Lei de Execuções Penais. Conforme previamente afirmado, em uma das hipóteses, o RDD adquire caráter de verdadeira sanção

\footnotetext{
104 STJ, HC n ${ }^{\circ}$ 40.300/RJ, 5 ${ }^{\mathrm{a}}$ Turma, Rel. Min. Arnaldo Esteves Lima, j. 07/06/2005, DJ 22/08/2005

${ }^{105}$ MIRABETE, Julio Fabbrini. FABBRINI, Renato N. Op. Cit, p.150.
} 
disciplinar (caput), enquanto nas demais constitui medida preventiva/cautelar $\left(\S \S 1^{\circ}\right.$ e $\left.2^{\circ}\right)$.

A lei, neste ponto, é muito criticada pela vagueza da linguagem empregada pelo legislador, pela imprecisão e amplitude de termos como "subversão à ordem e disciplina" e "alto risco para ordem e segurança". Abre-se, com isso, um elevado grau de discricionariedade ao intérprete, uma margem de atuação mais ampla e arbitrária, permitindo-se que a imagem comumente atribuída ao criminoso pela sociedade influencie julgamentos prévios acerca da periculosidade em potencial do preso e da necessidade dele ser alocado no regime disciplinar diferenciado.

Vejamos, pois, estas situações que legitimam a aplicação do regime disciplinar diferenciado, começando pela hipótese prevista no caput do art. 52.

\subsection{1 - Regime Disciplinar Diferenciado como punição disciplinar (art. 52 , caput)}

Art. 52 - a prática de fato previsto como crime doloso constitui falta grave e, quando ocasione subversão da ordem ou disciplina internas, sujeita o preso provisório, ou condenado, sem prejuízo da sanção penal, ao regime disciplinar diferenciado (...) (grifou-se e destacou-se)

A primeira hipótese, portanto, apresenta caráter de sanção disciplinar, aplicada em resposta ao cometimento de uma falta grave. No entanto, por se tratar da sanção mais rigorosa prevista na Lei $\mathrm{n}^{\circ} 7.210 / 84$, exige que o preso pratique fato previsto como crime doloso $\underline{\mathbf{e}}$ que tal conduta ocasione subversão da ordem ou disciplina internas.

Portanto, para que o preso possa ser alocado no regime disciplinar diferenciado por demonstrar indisciplina, é preciso que tenha praticado crime doloso e que sua conduta tenha impulsionado movimento de subversão à ordem interna. Quando o comportamento do preso caracteriza 
somente um desses fatores, configura falta grave punível mediante sanções previstas nos incisos III (suspensão ou restrição de direitos) e IV (isolamento na própria cela, nos locais que possuem alojamento), mas jamais dará ensejo ao RDD. ${ }^{106}$

Note-se que, na hipótese prevista no caput do art. 52, malgrado seja possível criticá-la por conta da vagueza e imprecisão do termo "subversão da ordem ou disciplina internas", ao menos neste caso a alocação do preso no regime disciplinar diferenciado é motivada por uma conduta prévia e prevista na lei.

Nesse contexto, ainda que questionáveis as condições oferecidas neste confinamento severo, ao menos a imposição do regime diferenciado exige do preso a prática de um fato determinado durante o cumprimento da pena. É dizer: a imposição do RDD seria uma reação a uma conduta de indisciplina praticada dentro da prisão, que se explicaria pela necessidade de zelar pelo normal funcionamento da unidade prisional.

Portanto, ao menos nesta situação a medida não é estimulada por pré-julgamentos e fatores que não estão associados à qualquer tipo de conduta. Quanto às demais hipóteses previstas em lei, o mesmo não se pode afirmar.

\subsection{2 - Regime Disciplinar Diferenciado como medida preventiva/cautelar $\left(\S \S 1^{\circ}\right.$ e $\left.2^{\circ}\right)$}

As hipóteses previstas nos parágrafos $1^{\circ}$ e $2^{\circ}$ do art. 52 da Lei de Execuções Penais não estão associadas ao cometimento de uma infração disciplinar, pois que o fundamento para a sua determinação não tem a feição punitiva característica de uma sanção. $\mathrm{Na}$ verdade, essas situações têm por escopo

${ }^{106}$ MIRABETE, Julio Fabbrini. FABBRINI, Renato N. Op. Cit, p.151. 
“(...) garantir as condições necessárias para que a pena privativa de liberdade ou a prisão provisória seja cumprida em condições que garantam a segurança do estabelecimento penal e a ordem pública, que continuaria ameaçada se, embora custodiado, permanecesse o preso em regime comum." ${ }^{107}$ (grifou-se e destacouse)

Como se vê, essas hipóteses se justificam por razões de segurança interna (do próprio estabelecimento prisional) e externa (da sociedade). Vejamos os termos dos $\S \S 1^{\circ}$ e $2^{\circ}$ do art. 52:

$\S 1^{\circ}$ - “o regime disciplinar diferenciado também poderá abrigar presos provisórios ou condenados, nacionais ou estrangeiros, que apresentem alto risco para a ordem e a segurança do estabelecimento penal ou da sociedade." $\$ 2^{\circ}$ - "estará igualmente sujeito ao regime disciplinar diferenciado o preso provisório ou o condenado sob o qual recaiam fundadas suspeitas de envolvimento ou participacão, a qualquer título, em organizacões criminosas, quadrilha ou bando." (grifou-se e destacou-se)

O $\S 1^{\circ}$, como se vê, aduz ser necessária a medida para presos que ofereçam "alto risco para a ordem ou segurança do estabelecimento penal ou da sociedade". O $\S 2^{\circ}$, por sua vez, impõe o regime aos presos sob os quais "recaiam fundadas suspeitas de envolvimento ou participação, a qualquer título, em organizações criminosas, quadrilha ou bando”.

A despeito do grau de abstração contido nas expressões destacadas, diziam as autoridades públicas e os defensores da medida que tais previsões se justificariam pelo imperativo de reforçar a segurança nas unidades prisionais, para proteger o próprio estabelecimento, bem como a sociedade, isolando criminosos que, por integrarem facções criminosas, seriam responsáveis por rebeliões e fugas dos presídios, ou, mesmo encarcerados, permaneceriam comandando e participando de organizações criminosas atuantes dentro e fora das prisões. ${ }^{108}$

No entanto, é preciso que se diga que, inobstante se faça necessário manter a ordem nos presídios, não se pode, sob essa justificativa, restringir garantias constitucionais e processuais dos presos utilizando-se o legislador

\footnotetext{
${ }^{107}$ MIRABETE, Julio Fabbrini. FABBRINI, Renato N. Idem, Ibidem.

${ }^{108}$ MIRABETE, Julio Fabbrini. FABBRINI, Renato N. Idem, p.149.
} 
de conceitos genéricos e abstratos, hábeis a dificultar a interpretação e gerar posicionamentos arbitrários.

Diante dessa terminologia vaga e imprecisa, há sérias dificuldades de se identificar objetivamente uma situação como sendo de alto risco, assim como não se determina precisamente quais suspeitas são fundadas ou não, qual a dimensão desse risco e dessa situação de suspeita capazes de levar o sujeito ao RDD.

Como já previamente debatido neste presente trabalho, o uso dessas expressões dúbias confere ampla margem de interpretação aos magistrados/agentes carcerários e demais autoridades públicas, podendo acarretar graves conseqüências ao acusado/preso, dado o grau de arbitrariedade que tem o intérprete no momento de definir o âmbito de incidência do texto legal.

No caso dos $\S \S 1^{\circ}$ e $2^{\circ}$ da LEP, expõe-se o agente à arbitrariedade e a subjetividade da autoridade penitenciária, em uma clara relativização do princípio da legalidade enquanto garantia fundamental do réu. ${ }^{109}$

Quanto a essa imprecisão terminológica do $\S \S 1^{\circ}$ e $2^{\circ}$ do art. 52, que confere ao magistrado arbítrio para valorar as situações que se encaixam na previsão legal, importante destacar a crítica de Paulo Cesar Busato:

\begin{abstract}
"A submissão ao regime disciplinar diferenciado deriva de um "alto grau de risco para a ordem e a segurança do estabelecimento penal ou da sociedade". Porém, a respeito de que estamos falando? Não seria da realização de um delito ou de uma falta grave regulada pela administração da cadeia, porque esta já se encontra referida na redação principal do mesmo artigo, que trata exatamente dela. Que outra fonte de risco social ou penitenciário podem decorrer de comissões que não sejam faltas nem delitos? E mais, a mera suspeita de participação em bandos ou organizações criminosas justifica o tratamento diferenciado. Porém, se o juízo é de suspeita, não há certeza a respeito de tal participação e, não
\end{abstract}

${ }^{109}$ CARVALHO, Themis Maria Pacheco de. O RDD como paradigma brasileiro do direito penal do inimigo. Disponível em: http://www2.mp.ma.gov.br/ampem/artigos/artigos2008/RDDParadigma-RECJ-05.09-08.pdf. Acesso em 11 de out de 2015. 
obstante, já aparece a imposição de uma pena diferenciada, ao menos no que se refere à sua forma de execução." ${ }^{110}$ (grifou-se e destacou-se)

Portanto, o legislador não foi claro ao definir as hipóteses em que cabível o regime disciplinar diferenciado, deixando ao arbítrio do Estado a eleição das situações que se encaixam ou não nos "riscos" e "suspeitas" de que trata a lei.

\section{5 - O REGIME DISCIPLINAR DIFERENCIADO COMO DIREITO PENAL DO INIMIGO}

Para além da crítica à terminologia vaga e imprecisa do dispositivo de lei em questão, as palavras de Busato parecem suscitar uma questão fundamental e diretamente associada ao fenômeno do direito penal do inimigo: nos $\S \S 1^{\circ}$ e $2^{\circ}$, não há uma conduta previamente estabelecida em lei que, se praticada, dá ensejo à alocação do sujeito no regime diferenciado.

Nesses casos, a medida não pressupõe a prática de um fato. Trata-se de uma responsabilidade pré-delitual, que antecede a realização de qualquer fato típico. ${ }^{111}$

Com isso, consagra-se de forma clara um adiantamento da punibilidade, já que o agente é levado a cumprir pena em regime mais

\footnotetext{
${ }^{110}$ BUSATO, Paulo César. "Regime disciplinar diferenciado como produto de um direito penal de inimigo”. Disponível em: http://www.mundojuridico.adv.br. In Mundo Jurídico Acesso em 12 jul de 2005, p.3.

${ }^{111}$ CARVALHO, Themis Maria Pacheco de. O RDD como paradigma brasileiro do direito penal do inimigo. Disponível em: http://www2.mp.ma.gov.br/ampem/artigos/artigos2008/RDDParadigma-RECJ-05.09-08.pdf. Acesso em 11 de out de 2015.
} 
severo sem que tenha cometido qualquer ato ou exteriorizado qualquer conduta apta a ensejá-lo. ${ }^{112}$

Nos termos da legislação, parece claro que o agente se submete ao regime disciplinar diferenciado em função do que representa, isto é, alguém considerado pelos magistrados e demais intérpretes da lei como de alto risco para a sociedade ou estabelecimento prisional. Não se cogita do que possa ter feito no presídio.

Dentro desse cenário, criam-se uma série de restrições que não são propriamente dirigidas a fatos, mas a uma classe de autores específica. Trata-se, sem dúvida, de uma expressão de direito penal do autor, que rompe com a essência de um direito penal democrático e subsidiário, tal como prescrito na Constituição Federal. Tal classe de indivíduos,

(...) segundo o julgamento dos responsáveis pelas instâncias de controle penitenciário, representam um risco social e/ou administrativo ou são "suspeitas" de participação em bandos ou organizações criminosas. Esta iniciativa conduz, portanto, a um perigoso direito penal de autor, onde "não importa o que se faz ou omite (o fato) e sim quem - personalidade, registros e características do autor faz ou omite (a pessoa do autor)". ${ }^{113}$

A toda evidência, as hipóteses em questão constituem violações a princípios basilares do direito penal. Assim é que a alocação do preso no RDD com base no suposto risco que ele representa para a sociedade ou presídio rompe com a lógica da punição fundada na culpabilidade, na avaliação do seu comportamento a partir da exteriorização de uma conduta.

No mesmo sentido, a mera suspeita fundada de envolvimento ou participação em organização criminosa já autoriza a submissão do agente ao regime, relativizando-se garantias fundamentais como a ampla defesa e o

112 BERTI, Natália. O regime disciplinar diferenciado como expressão do direito penal do inimigo. Disponível emhttp://condominioelocazioni.diritto.it/docs/32034-o-regime-disciplinardiferenciado-como-express-o-do-direito-penal-do-inimigo. Acessoem 26 de set. de 2013.

${ }^{113}$ BUSATO, Paulo César. "Regime disciplinar diferenciado como produto de um direito penal de inimigo”. Disponível em: http://www.mundojuridico.adv.br. In Mundo Jurídico Acesso em 12 jul de 2005 , p. 4 . 
contraditório (art. 5, $\mathrm{LV}$ ) e, sobretudo, a presunção da inocência (art. $5^{\circ}$, LVII), eis que o sujeito é confinado no RDD com base em suposições. ${ }^{114}$

Em tais hipóteses, como se vê, pune-se o sujeito, no estado prévio, por presunção de periculosidade, com base no que ele representa ou em mera suspeita de envolvimento em grupos criminosos, nos moldes da construção de Jakobs sobre legislações de direito penal do inimigo.

Desse modo, conclui-se que aqui incide diretamente o aludido fenômeno: determinado grupo de indivíduos somente é considerado a partir do caráter perigoso que ostenta. Consequentemente, permite-se um tratamento diferenciado, negando-se a eles os mesmos direitos e garantias proporcionados aos demais. O resultado desse processo é justamente a instituição de medidas mais repressivas e arbitrárias, das quais o regime disciplinar é espécie. Nesse caso, o legislador

“(...) acabou por institucionalizar profunda dicotomia entre os presos portadores de direitos e os inimigos. Em relação a estes, o Estado passa a não ter qualquer responsabilidade social, voltando seus mecanismos para combater permanentemente sua forma de vida perigosa." 115

Opera-se, assim, uma verdadeira quebra ao princípio da igualdade, impondo-se uma reação penal diferenciada conforme o perfil do autor, tratando-se ele de um criminoso comum ou de um criminoso supostamente perigoso.

Como reflexo desse tratamento diferenciado, para os inimigos a pena não adquire qualquer caráter de ressocialização, tornando-se verdadeira estratégia de neutralização. Não há como supor que haja qualquer perspectiva de alguém ser ressocializado passando vinte e duas horas do seu

\footnotetext{
114 BERTI, Natália. O regime disciplinar diferenciado como expressão do direito penal do inimigo. Disponível emhttp://condominioelocazioni.diritto.it/docs/32034-o-regime-disciplinardiferenciado-como-express-o-do-direito-penal-do-inimigo. Acessoem 26 de set. de 2013.

115 CARVALHO, Salo de. FREIRE, Christiane Russomano "O regime disciplinar diferenciado: notas críticas à reforma do sistema punitivo brasileiro”. Disponível na internet: http://www.defensoria.sp.gov.br/dpesp/Repositorio/30/Documentos/273.pdf. In Revista Transdisciplinar de Ciências Penitenciárias, 4(1):p. 23, Jan-Dez./2005.
} 
dia isolado, alheio a qualquer tipo de contato. A ideia é justamente a de segregar, afastando os reputados perigosos do convívio com os demais presos.

\section{6 - PERICULOSIDADE E O ESTEREÓTIPO CRIMINAL}

Note-se que, dentro desse contexto, a alocação do preso no regime disciplinar diferenciado ainda é permeada por uma noção de periculosidade, a qual é demasiado subjetiva. Não há como negar que, dentro desse processo de tomada de decisão, recorre-se ao ideal de perigo socialmente construído no Brasil, identifica-se mais facilmente a ameaça a partir de critérios específicos e naturalmente assimilados pelo senso comum. Desse modo, leva-se em consideração a cor, idade, condição social, escolaridade, habitação do acusado/preso, dentre outros aspectos associados à sua personalidade.

Conforme amplamente debatido no segundo capítulo deste trabalho, construiu-se no país um estereótipo criminal associado à figura do pobre $\mathrm{e}$ do traficante de drogas, imagem esta que se fortaleceu com o tempo, muito em função dos apelos dos meios de comunicação de massa. Na prática, tal ideia, de tão difundida, fora espontaneamente assimilada e, de certa forma, naturalizou visões preconceituosas por parte dos brasileiros em relação à determinada classe de pessoas. Neste processo, não está alheia a justiça criminal, igualmente composta por brasileiros que, como tais, estão inseridos dentro dessa realidade.

Sendo assim, tendo em mente todo esse processo histórico e social de criação de estereótipos criminais e sabendo-se da realidade das grandes metrópoles brasileiras na atualidade, nunca é demais lembrar que, tendo sido o acusado preso pela polícia por suposto crime de tráfico de drogas, a possibilidade de que venha a ser posteriormente alocado no regime disciplinar diferenciado é maior do que a média, tendo em vista a imagem 
atribuída ao traficante de drogas como inimigo público. O diagnóstico se agrava se o preso é pobre, favelado e apresenta antecedentes criminais.

Afinal, tendo em vista que ostenta o típico perfil do crime, evidente que representa "alto risco para a ordem e a segurança do estabelecimento penal e da sociedade", preenchendo o requisito constante do $\S 1^{\circ}$ do art. 52 da Lei de Execuções Penais. A solução, o regime disciplinar diferenciado. 


\section{CAPÍTULO 5 - CONSIDERAÇÕES FINAIS}

\section{1 - DIREITO PENAL DO INIMIGO: POLÍTICA DE SEGURANÇA FALHA NO BRASIL}

Conforme amplamente debatido neste trabalho, trata-se o direito penal do inimigo de um processo de ampliação da repressão do Estado em relação à determinada classe de indivíduos, a quem se combate em função da periculosidade que representa.

De tais sujeitos não há expectativa de um comportamento conforme a norma, de um convívio pacífico em sociedade. Desse modo, a estes é negada a condição de ser humano, passando a ser reconhecidos única e exclusivamente como uma ameaça à ordem estabelecida.

Assim sendo, para combater o perigo, mobilizam-se as forças policiais, criam-se leis restritivas de garantias penais e processuais fundamentais e legitimam-se excessos ditos inevitáveis, de modo a garantir a segurança da sociedade.

No entanto, conforme enunciado neste trabalho, tal discurso ignora todas as razões históricas e sociais que criam as bases para que os ditos "inimigos" possam se desenvolver, identificando a violência e o mal por eles perpetrado como fato já concebido, sob a perspectiva pura e simples da realidade atual.

Como visto previamente, a partir da abordagem de Zaffaroni, ao longo do tempo a face do inimigo se modificou, assim como a retórica hábil a justificar o tratamento diferenciado implementado, justamente porque a individualização desta classe de sujeitos sempre fora realizada de maneira arbitrária por parte das instâncias de poder, com o objetivo de manter a ordem e a hierarquização social intactas. 
No Brasil, é flagrante a permanência de um processo de estigmatização da população pobre e negra que, desde a época da colonização e da cultura de escravidão, viu-se excluída da vida política, social e econômica. No país, o fenômeno do direito penal do inimigo incidiu na maior parte do tempo sobre essa parcela do povo.

Assim, não é de se surpreender que, na atualidade, o estereótipo do criminoso brasileiro tenha se constituído sobre a figura de jovens pobres, de pele escura, moradores de áreas periféricas.

Fato é que, nas grandes metrópoles do país, vivemos um cenário de guerra constante, que se repete ao longo do tempo: diante do imenso contraste existente entre os habitantes nas cidades, aumentam os índices de violência. Com o desenvolvimento do tráfico de drogas, declara-se definitivamente guerra aos traficantes e assimila-se uma ideia da favela como lócus do mal. Na tentativa de dar uma resposta à sociedade, são realizadas operações policiais violentas, tornando-se comuns os confrontos armados.

Nesse contexto, devido à instabilidade e aos anseios da população por maior segurança, são editadas leis extremamente repressivas e que instituem medidas penais e processuais demasiado restritivas (Lei de Crimes Hediondos, Lei de Drogas, instituição do RDD, etc). Com isso, amplia-se o aparato repressivo do Estado, intensificando-se os esforços policiais, bem como a vigilância e o controle sobre a população pobre.

Todo esse fenômeno atende ao mito de que, mediante o endurecimento da lei penal, é possível amenizar o mal, diminuir os índices de violência e criar uma situação de tranquilidade social. No entanto, na prática, os números demonstram como a violência não se reduz a partir dessas medidas.

Talvez o maior exemplo da ausência de efetividade dessa tendência tenha sido a adoção da Lei de Crimes Hediondos (Lei ${ }^{\circ}{ }^{8}$ 8.072/90), a qual, 
com o objetivo de oferecer uma resposta à onda de violência que assolava o país, restringiu garantias penais e processuais aos acusados da prática de crimes reputados graves. Na prática, não houve redução dos crimes a partir de 1990: pelo contrário, a maioria deles aumentou.

$\mathrm{Na}$ verdade, grande parte dessas legislações típicas de um direito penal do inimigo traduzem medidas de emergência, editadas no afã de responder rapidamente ao clamor público, às exigências imediatas por ordem e segurança. Todavia, a experiência vem demonstrando que tais medidas são ineficazes, sem que cumpram as finalidades esperadas pela sociedade.

Para agravar a situação, dentro desse fenômeno de ampliação do poder punitivo, assistimos a um processo de naturalização da barbárie: a violência é banalizada, as mortes ocorridas em operações policiais são constantes, as comunidades pobres se tornam verdadeiro cenário de batalha, em detrimento da população local.

Nessas operações policiais, igualmente permeadas pela imagem socialmente construída de um criminoso (preto, pobre e favelado), muitas vezes os resultados alcançados são desastrosos, vitimando civis inocentes, moradores da periferia.

Isso porque, estreitando-se os mecanismos de vigilância e combate a determinada classe de indivíduos, pune-se mais e, no bojo deste processo, inclui-se figuras alheias ao crime, selecionadas por se adequarem ao estereótipo criminal.

Todo esse empenho para redução da violência através da repressão não é recente e vem se repetindo com o passar dos anos. Em comum, a crença propagada no senso comum de que é possível conter a criminalidade a partir do recrudescimento da lei e da intensificação dos esforços policiais. Na prática, porém, os números vêm demonstrando justamente a ineficácia dessas políticas de segurança pública. 


\section{2 - PRISÕES PREVENTIVAS E RDD: ASPECTOS JURÍDICOS COMUNS QUE FAVORECEM A OCORRÊNCIA DO FENÔMENO}

Quanto aos institutos da legislação analisados neste trabalho, é de se observar que ambas as previsões legislativas se aproximam em alguns aspectos, hábeis a estimular a configuração do fenômeno do direito penal do inimigo.

O primeiro deles é a vagueza da linguagem empregada pelo legislador, que se utiliza de terminologias demasiado imprecisas, que demandam uma interpretação valorativa por parte do julgador.

Como se sabe, a aplicação da lei no direito sempre pressupõe um trabalho de interpretação por parte daquele que a aplica. Em praticamente todos os casos, de nada importa o texto puro e simples da lei, mas sim a norma que dele é extraída por parte do intérprete.

Sendo assim, nas hipóteses em que há extrema indeterminação em seus termos, essa margem de interpretação é em muito ampliada, conferindo ao intérprete acentuado grau de discricionariedade. Com isso, os casos são decididos com elevadas doses de subjetivismo, sendo predominante para a solução concreta a concepção individual de cada julgador, criando um ambiente de verdadeira insegurança jurídica.

Na legislação penal, essa situação é ainda agravada pelo fato de a situação concreta envolver pretensões extremamente valiosas, por estar em jogo a liberdade do indivíduo. É justamente por isso que vigora o princípio da máxima-taxatividade, corolário da legalidade, que exige a elaboração de normas penais de maneira taxativa e com a maior precisão técnica possível, de modo que seja viável a qualquer pessoa identificar objetivamente a hipótese concreta que se pretendeu criminalizar. 
Sendo assim, diante desse quadro, conclui-se que o emprego de termos como "ordem pública", "alto risco para a sociedade" ou "fundadas suspeitas" não se coadunam com a essência da atividade legislativa em matéria penal, por se tratarem de conceitos abertos, que conferem ao intérprete ampla margem de atuação. É justamente essa liberdade garantida aos julgadores que lhes permite interpretar a lei de maneira autoritária, de acordo com a sua própria concepção da realidade.

Com isso, a imprecisão do texto muitas vezes acarreta distorções absurdas no sentido atribuído a determinado instituto, banalizando-se uma interpretação totalmente em desconformidade com a sua essência, como é o caso das prisões preventivas, que detém (ou ao menos deveriam deter) caráter excepcional.

Ademais, essa indeterminação conceitual permite que elementos que nada tem de jurídico influenciem diretamente no trabalho de interpretação, dentre eles, a compreensão que um magistrado tem acerca de um criminoso. Trata-se, acima de tudo, de uma expressão opinativa que não deveria prevalecer no processo penal.

A segunda característica comum entre os institutos apresentados é o fato de que ambos estão permeados por um juízo de periculosidade, por um conceito extremamente dúbio e que se distancia em muito de um direito penal do fato.

A periculosidade constitui um aspecto da personalidade de determinado sujeito, uma característica que identifica determinado indivíduo. Portanto, prisões ou alocações no regime disciplinar diferenciado fundadas na periculosidade do agente não estão associadas a condutas por ele praticadas previamente, mas no risco de que venham a praticá-las no futuro. Supõe-se que, por conta do perigo que representam, voltarão a atormentar a sociedade. 
Novamente, trata-se de um juízo subjetivo do julgador, que interpretará o caso com base nas concepções pessoais que detém acerca de um criminoso perigoso, sem que se apresentem critérios objetivos a legitimar a sua atividade.

Assim, diante desse cenário, para que esse atuar característico de um processo social discriminatório e reflexo de um direito penal do inimigo possa ser restringido, necessário se faz redefinir os institutos legislativos que permitem o seu desenvolvimento, reduzindo-se o espaço de interpretação conferido pela lei aos magistrados. Nesse sentido, oportuno destacar as lições de Beccaria:

"o juiz deve fazer um silogismo perfeito. A maior deve ser a lei geral; a menor, a ação conforme ou não à lei; a consequência, a liberdade ou a pena. Se o juiz for constrangido a fazer um raciocínio a mais, ou se o fizer por conta própria, tudo se torna incerto e obscuro". 116

De fato, em uma situação ideal, se as leis penais fossem fixas e literais, de modo a demonstrar claramente a forma de serem interpretadas e aplicadas ao caso concreto, mais fácil seria a sua fiscalização por parte dos demais e dos próprios acusados, gerando maiores embaraços àqueles que as aplicassem de forma distorcida, levando em consideração o status do criminoso e demais preconceitos difundidos dentro da sociedade. ${ }^{117}$

Conclui-se, portanto, que a adoção de normas penais claras e bem definidas contribui para o controle da atividade judicial, privando os jurisdicionados de idiossincrasias dos magistrados, evitando-se distorções de interpretação, posicionamentos arbitrários e gerando segurança e previsibilidade.

Por fim, se subsistem dúvidas de interpretação, o parâmetro decisional deve ser a Constituição Federal e não as expressões opinativas de cada julgador.

\footnotetext{
${ }^{116}$ BECCARIA, Cesare. Dos delitos e das Penas. Rio de Janeiro: Ed. De Ouro, 1965, p.35.

117 THOMPSON, Augusto. Op. Cit, p.34.
} 


\section{6 - BIBLIOGRAFIA}

AGACHE, Alfred. Cidade do Rio de Janeiro: Remodelação, Extensão e Embelezamento. Paris: Foyer Brésilien, 1930.

ALMEIDA, Gabriel Bertin de. Afinal, quando é possível a decretação de prisão preventiva para a garantia da ordem pública?. In Revista Brasileira de Ciências Criminais. São Paulo, no 44, p. 71-85, jul-set/2003.

BATISTA, Nilo. Política criminal com derramamento de sangue. In: Revista Brasileira de Ciências Criminais, ano 5, no 20, outubro-dezembro de 1997. São Paulo: IBCCRIM/Revista dos Tribunais, 1997.

BATISTA, Vera Malaguti. Dificeis ganhos fáceis - drogas e juventude pobre no Rio de Janeiro. $1^{\text {a }}$ ed. Rio de Janeiro: Revan, 2003.

BATISTA, Vera Malaguti. O medo na cidade do Rio de Janeiro. Dois tempos de uma historia. $2^{\mathrm{a}}$ ed. Rio de Janeiro: Revan, 2009.

BECCARIA, Cesare. Dos delitos e das Penas. Rio de Janeiro: Ed. De Ouro, 1965.

BERTI, Natália. O regime disciplinar diferenciado como expressão do direito penal do inimigo. Disponível emhttp://condominioelocazioni.diritto.it/docs/32034-o-regime-disciplinardiferenciado-como-express-o-do-direito-penal-do-inimigo. Acesso em 26 de set. de 2013.

BUSATO, Paulo César. Regime disciplinar diferenciado como produto de um direito penal de inimigo. Disponível em: http://www.mundojuridico.adv.br. In Mundo Jurídico Acesso em 12 jul de 2005.

CAPEZ, Fernando. Curso de Processo Penal. $12^{\mathrm{a}}$ ed. São Paulo: Saraiva, 2005.

CARVALHO, Salo de. FREIRE, Christiane Russomano "O regime disciplinar diferenciado: notas críticas à reforma do sistema punitivo brasileiro". Disponível na internet: http://www.defensoria.sp.gov.br/dpesp/Repositorio/30/Documentos/273.pdf - Artigo publicado na Revista Transdisciplinar de Ciências Penitenciárias, 4(1):7-26, Jan-Dez./2005

CARVALHO, Themis Maria Pacheco de. O RDD como paradigma brasileiro do direito penal do inimigo. Disponível em: 
http://www2.mp.ma.gov.br/ampem/artigos/artigos2008/RDDParadigmaRECJ-05.09-08.pdf. Acesso em 11 de out de 2015.

CHALOUB, Sidney. Cidade febril: cortiços e epidemias na Corte imperial. São Paulo: Companhia das Letras, 1996.

COIMBRA, Cecília Maria Bouças. Direitos Humanos e criminalização da pobreza. Disponível em: http://www.slab.uff.br/images/Aqruivos/textos_sti/Cec\%C3\%ADlia\%20Coi mbra/texto54.pdf . Acesso em 22 de set 2015.

DEL OLMO, Rosa. A América Latina e sua criminologia, $1^{\mathrm{a}}$ ed. Rio de Janeiro: Revan, 2004.

DORNELLES, João Ricardo. Direitos Humanos, violência e barbárie no Brasil: uma ponte entre o passado e o presente In: Bethania Assy; Carolina Campos Melo; João Ricardo W. Dornelles; José Maria Gómez. (Org.). "Direitos Humanos, Justiça, Verdade e Memória" - 1ª ed. Vol. 1. Rio de Janeiro: Lumen Juris Editora, 2012.

DOS SANTOS, Astério Pereira. Regime Disciplinar Especial - Legalidade e Legitimidade. Disponível em: http://www.seap.rj.gov.br, Acesso em 22 de ago de 2014.

FOUCAULT, Michel. A verdade e as formas jurídicas. Rio de Janeiro: PUC/RJ e Nau Editora, 2001

GARCIA, Manuel Salvador Grosso. Qué es y qué puede ser el Derecho penal del enemigo? Una aproximación crítica al concepto. In: MELIÁ, Manuel Cancio e DIEZ, Gomés-Jara (coord.). Derecho Penal del Enemigo: el Discurso de la Exclusion, vol. 2. Madrid: Edisofer, 2006

JAKOBS, Günther. MELIÁ, Manuel Cancio. Derecho Penal Del enemigo, $1^{a}$ ed. Madrid: Civitas, 2003

JAKOBS, Günther. MELIÁ, Manuel Cancio. Direito Penal do Inimigo: Noções e Críticas, $6^{\mathrm{a}}$ ed. Porto Alegre: Livraria do Advogado, 2012.

JARDIM, Afrânio Silva. Direito Processual Penal. $11^{\mathrm{a}}$ ed. Rio de Janeiro: Forense, 2002.

LOPES JÚNIOR, Aury. Prisões Cautelares. $4^{\mathrm{a}}$ Ed. São Paulo: Saraiva, 2013

MIRABETE, Julio Fabbrini. FABBRINI, Renato N. Execução Penal, 12a ed. São Paulo: Atlas, 2014.

RAMALHO, José Ricardo. O mundo do crime: a ordem pelo avesso. Rio de Janeiro: Graal, 1979. 
RANGEL, Paulo. Direito Processual Penal, $16^{\mathrm{a}}$ ed. Rio de Janeiro: Lumen Juris, 2009.

RODRIGUES, Thiago. Narcotráfico: uma guerra na guerra. São Paulo: Desativo, 2003.

SALLES, Marcelo. Comunicação e Controle Social, In Revista de Política e Cultura da ADUFF: Violência, Mídia e Criminalização da Pobreza, Ano I $\mathrm{n}^{\circ} 2, \quad 2008.2$ Disponível em: http://www.aduff.org.br/publicacoes/200812_classe_2.pdf. Acesso em 05 de Nov 2015.

SANGUINÉ, Odone. A inconstitucionalidade do clamor público como fundamento da prisão preventiva. In Revista de Estudos Criminais. Porto Alegre, nº10, 2003.

SILVA, Ivan Carlos da. $O$ direito penal do inimigo. Disponível na internet: http://unisinos.br/blogs/ndh/2013/07/29/o-direito-penal-do-inimigo/, Acesso em 29 de jul de 2013.

SOUZA, Renato Perrotta de. A inconstitucionalidade da prisão preventiva decretada como garantia da ordem pública. Disponível na internet: http://www.emerj.tjrj.jus.br/paginas/trabalhos conclusao/1semestre2013/tra balhos_12013/RenatoPerrottaSouza.pdf. Rio de Janeiro, 2013.

THOMPSON, Augusto. Quem são os criminosos? 2a Ed. Rio de Janeiro: Lumen Juris, 2007.

TOURINHO FILHO, Fernando da Costa. Código de Processo Penal Comentado. $6^{\text {a }}$ ed. Vol. 1. São Paulo: Saraiva, 2001.

ZACCONE, Orlando. Os acionistas do nada: quem são os traficantes de drogas. $3^{\mathrm{a}}$ Ed. Rio de Janeiro: Revan, 2007.

ZAFFARONI, E. Raul. O inimigo no Direito Penal, $3^{\mathrm{a}}$ ed. Rio de Janeiro: Revan, 2011. 